\title{
ANNOTATED CHECKLIST OF THE ECHINODERMS FROM THE KIUNGA MARINE NATIONAL RESERVE, KENYA. PART I: ECHINOIDEA AND HOLOTHUROIDEA
}

\author{
Yves Samyn, Edward Vanden Berghe* \\ Free University of Brussels, Department of Biology, \\ Unit for Ecology \& Systematics, \\ Pleinlaan 2, B-1050 Brussels, Belgium \\ ysamyn@vub.ac.be
}

\begin{abstract}
The echinoderm fauna of the Kiunga Marine National Reserve, Kenya, is documented, based on the results of a field trip, and additional information from the literature. In this first paper, the Holothuroidea and Echinoidea are discussed. A total of 91 specimens representing eight orders, 13 families, 19 genera and 37 species were collected. Five other species were not collected but were identified in the field. Six additional species are reported from literature only and are not discussed. Diagnostic characters of every species recorded are given, as well as an assessment of their abundance in the Kiunga Marine Reserve. Clypeaster rarispinus, Phyllacanthus imperialis, Microcyphus rousseaui (Echinoidea), Holothuria (Cystipus) rigida, Holothuria (Platyperona) difficilis, Labidodemas pertinax, Stichopus chloronotus and Stichopus cf. monotuberculatus (Holothuroidea) are new records for Kenya. Holothuria (Theelothuria) turriscelsa is a new record for the Indian Ocean. This study stresses the importance of the Kiunga Marine National Reserve as a sanctuary in the conservation of the marine invertebrate fauna.
\end{abstract}

\section{INTRODUCTION}

Few basic studies have been undertaken to map the distribution of echinoderms in the western Indian Ocean. All information available for echinoderms of shallow-water of the Indo-West Pacific Ocean was reviewed by Clark \& Rowe (1971). This work is now at least partly outdated; also, the scale with which the distributions were mapped is too coarse to support management of these important natural resources. Humphreys (1981) lists all species of echinoderms in the Watamu/Malindi area, and in parts of Tanzania. Richmond (1997) compiled a book on most fauna and flora groups of the seashores of eastern Africa, including a chapter on echinoderms (Rowe \& Richmond, 1997). But again, geographical ranges are too broad for management purposes. Tortonese $(1949,1951,1980)$ studied the echinoderms of

\footnotetext{
* Current address: Flanders Marine Data Centre, Victorialaan 3 B-8400, Oostende, Belgium.
} 
the Somali coast. Obura et al. (1998) surveyed the Kiunga Marine Reserve, but unfortunately did not take any specimens; so their identifications must be treated with caution.

This expedition was a joint effort of the Free University of Brussels (Unit of Ecology \& Systematics), WWF Kenya and Kenya Wildlife Service. Collecting was done by handpicking at low tide, by snorkeling and by SCUBA diving up to depths of $31 \mathrm{~m}$, from 3 to 12 May, 1999. Destructive sampling techniques like dredging were never used.

Analogous to Sloan et al. (1979), detailed taxonomic descriptions and geographical distributions are not included; instead we refer to major works (Clark \& Rowe, 1971; Clark \& Courtman-Stock, 1976; Rowe \& Doty, 1977; Cherbonnier, 1988; Rowe \& Gates, 1995; Massin, 1996a, 1999) from which the original descriptions and geographical distributions can be traced. A brief field description is included, as are important records for eastern Africa and the western Indian Ocean.

\section{STUDY REGION}

The Kiunga Marine National Reserve was gazetted in 1979 as a Marine National Reserve and at $250 \mathrm{~km}^{2}$ is the largest marine reserve in Kenya. It is part of the Bajuni Archipelago, which lies at the northernmost extremity of the Kenya coast, bordering Somalia. The seven islands of the archipelago are fringed with mangrove forests, surrounded by extensive seagrass beds and coral reefs. The area is important for biodiversity, and provides nesting sites for marine turtles and migratory birds (Obura et al., 1998). Table 1 lists the names and coordinates of the different sampling sites within the Reserve, together with the depth ranges (see also figure 1).

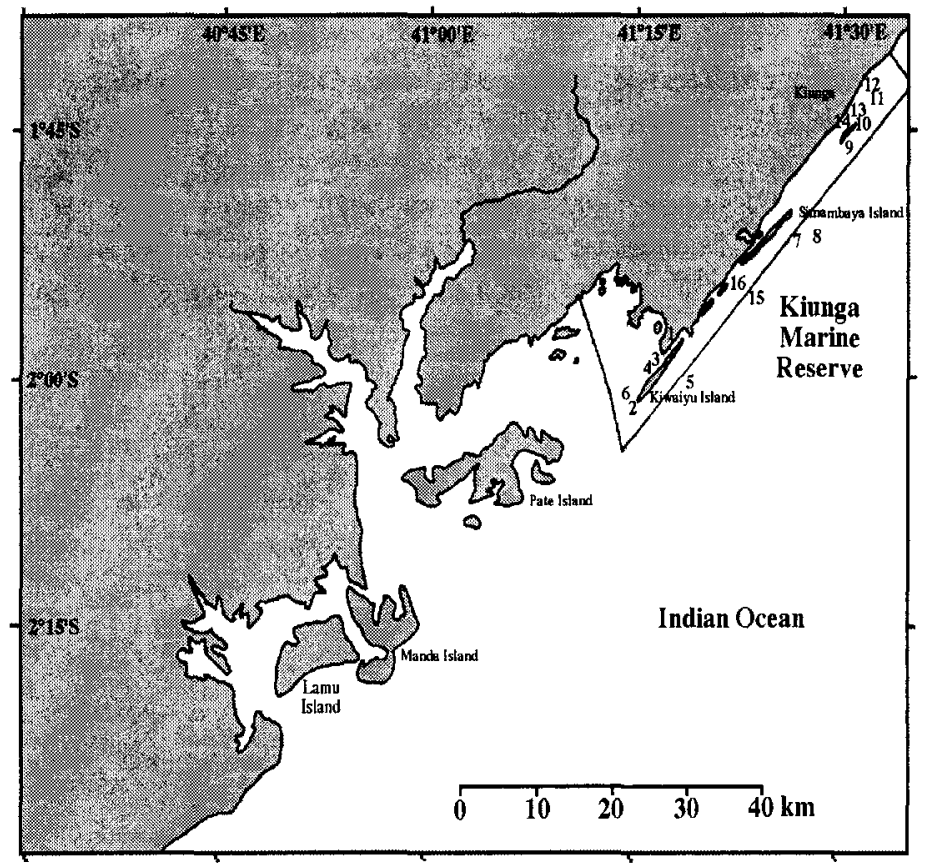

Figure 1. Map with observation and collection sites in the Kiunga Marine Reserve. (1) Mkomani; (2) Kilima Nungu; (3) Mike's Outer Reef; (4) Mike's Inner Reef; (5) Chongo cha Chano; (6) Shimo la Tewa; (7) Chongo cha Kui; (8) Kui; (9) Mwamba Mkuu; (10) Mlango wa Bomani; (11) Wreck; (12) Kaddhika; (13) Mwamba wa Boso; (14) Kiunga Camp; (15) Chongo cha Mvundeni; (16) Hindi. 
Table 1. Names and coordinates of the different sampling and observation sites in the Kiunga Marine Reserve. Depths apply to the low water level.

\begin{tabular}{|c|c|c|c|c|c|}
\hline Date & Site Name & Region & Depth range $(\mathrm{m})$ & Latitude & Longitude \\
\hline $4 / 4 / 99$ & Mkomani & Kiwaiyu & $1-4$ & $01^{\circ} 57^{\prime} 42^{\prime \prime} \mathrm{S}$ & $41^{\circ} 18^{\prime} 02^{\prime \prime} \mathrm{E}$ \\
\hline $4 / 4 / 99$ & Kilima Nungu & Kiwaiyu & $4-8$ & $02^{\circ} 02^{\prime} 40^{\prime \prime} \mathrm{S}$ & $41^{\circ} 15^{\prime} 55^{\prime \prime} \mathrm{E}$ \\
\hline $5 / 4 / 99$ & Mike's Outer Reef & Kiwaiyu & $1.5-3$ & $01^{\circ} 59^{\prime} 39^{\prime \prime} \mathrm{S}$ & $41^{\circ} 17^{\prime} 28^{\prime \prime} \mathrm{E}$ \\
\hline $5 / 4 / 99$ & Mike's Inner Reef & Kiwaiyu & $5-8$ & $01^{\circ} 59^{\prime} 40^{\prime \prime} \mathrm{S}$ & $41^{\circ} 17^{\prime} 28^{\prime \prime} \mathrm{E}$ \\
\hline $6 / 4 / 99$ & Chongo cha Chano & Kiwaiyu & $8-17$ & $02^{\circ} 00^{\prime} 29^{\prime \prime} \mathrm{S}$ & $41^{\circ} 20^{\prime} 01^{\prime \prime} \mathrm{E}$ \\
\hline $6 / 4 / 99$ & Shimo la Tewa & Kiwaiyu & $3-7$ & $02^{\circ} 02^{\prime} 35^{\prime \prime} \mathrm{S}$ & $41^{\circ} 14^{\prime} 47^{\prime \prime} \mathrm{E}$ \\
\hline $7 / 4 / 99$ & Chongo cha Kui & Kui & $12-21$ & $01^{\circ} 52^{\prime} 02^{\prime \prime} \mathrm{S}$ & $41^{\circ} 26^{\prime} 55^{\prime \prime} \mathrm{E}$ \\
\hline $7 / 4 / 99$ & Kui & Kui & $1-4$ & $01^{\circ} 49^{\prime} 29^{\prime \prime} \mathrm{S}$ & $41^{\circ} 26^{\prime} 43^{\prime \prime} \mathrm{E}$ \\
\hline $8 / 4 / 99$ & Mwamba Mkuu & Kiunga & $7-17$ & $01^{\circ} 46^{\prime} 10^{\prime \prime} \mathrm{S}$ & $41^{\circ} 30^{\prime} 38^{\prime \prime} \mathrm{E}$ \\
\hline $8 / 4 / 99$ & Mlango wa Bomani & Kiunga & $1-5$ & $01^{\circ} 44^{\prime} 37^{\prime \prime} \mathrm{S}$ & $41^{\circ} 31^{\prime} 09^{\prime \prime} \mathrm{E}$ \\
\hline $9 / 4 / 99$ & Wreck & Ishakani & $6-10$ & $01^{\circ} 43^{\prime} 14^{\prime \prime} \mathrm{S}$ & $41^{\circ} 32^{\prime} 48^{\prime \prime} \mathrm{E}$ \\
\hline $9 / 4 / 99$ & Kaddhika & Ishakani & $1-3$ & $01^{\circ} 43^{\prime} 04^{\prime \prime} \mathrm{S}$ & $41^{\circ} 32^{\prime} 28^{\prime \prime} \mathrm{E}$ \\
\hline $9 / 4 / 99$ & Mwamba wa Boso & Kiunga & $1-3$ & $01^{\circ} 44^{\prime} 18^{\prime \prime} \mathrm{S}$ & $41^{\circ} 31^{\prime} 34^{\prime \prime} E$ \\
\hline $9 / 4 / 99$ & Kiunga Camp & Kiunga & $1-8$ & $01^{\circ} 45^{\prime} 14^{\prime \prime} \mathrm{S}$ & $41^{\circ} 30^{\prime} 35^{\prime \prime} \mathrm{E}$ \\
\hline $10 / 4 / 99$ & Mwamba Mkuu & Kiunga & $8-22$ & $01^{\circ} 44^{\prime} 39^{\prime \prime} \mathrm{S}$ & $41^{\circ} 31^{\prime} 15^{\prime \prime} \mathrm{E}$ \\
\hline $10 / 4 / 99$ & Kui & Kui & $0.5-5$ & $01^{\circ} 49^{\prime} 29^{\prime \prime} \mathrm{S}$ & $41^{\circ} 26^{\prime} 43^{\prime \prime} \mathrm{E}$ \\
\hline $11 / 4 / 99$ & Chongo cha Mvundeni & Rubu & $8-28$ & $01^{\circ} 55^{\prime} 29^{\prime \prime} \mathrm{S}$ & $41^{\circ} 23^{\prime} 35^{\prime \prime} \mathrm{E}$ \\
\hline $11 / 4 / 99$ & Hindi & Rubu & $1-5$ & $01^{\circ} 54^{\prime} 25^{\prime \prime} \mathrm{S}$ & $41^{\circ} 22^{\prime} 22^{\prime \prime} \mathrm{E}$ \\
\hline $12 / 4 / 99$ & Chongo cha Chano & Kiwaiyu & $11-31$ & $02^{\circ} 00^{\prime} 35^{\prime \prime} \mathrm{S}$ & $41^{\circ} 19^{\prime} 58^{\prime \prime} \mathrm{E}$ \\
\hline $12 / 4 / 99$ & Mike's Outer Reef & Kiwaiyu & $1-4$ & $01^{\circ} 59^{\prime} 39^{\prime \prime} \mathrm{S}$ & $41^{\circ} 17^{\prime} 29^{\prime \prime} \mathrm{E}$ \\
\hline $12 / 4 / 99$ & Kilima Nungu & Kiwaiyu & $4-8$ & $02^{\circ} 02^{\prime} 40^{\prime \prime} \mathrm{S}$ & $41^{\circ} 15^{\prime} 55^{\prime \prime} \mathrm{E}$ \\
\hline
\end{tabular}

\section{RESULTS}

A total of 91 specimens representing 37 species were collected. An overview of the echinoids and holothurians from the Kiunga Marine Reserve (Obura et al, 1998; this study) compared to the echinoid and the holothurian fauna of Kenya (Levin, 1979: holothurians only; Humphreys, 1981) and Somalia (Tortonese, 1949-1951; 1951; 1980) is given in table 2. Several important 'historical papers' also describe echinoderms collected in the region of interest. These are not included in table 2, but are separately discussed in the systematic account. A species is considered to belong to the echinoderm fauna of the Kiunga Marine Reserve if it is reported by us or if it is reported from both Somalia and Kenya.

An indication of abundance in the Kiunga Marine Reserve is given in four categories:

- Very rare: only one or two specimens seen during the survey;

- Rare: spotted up to five specimens during the survey;

- Common: seen up to 20 specimens during the survey;

- Abundant: spotted more than 20 specimens during the survey.

\section{SYSTEMATIC ACCOUNT}

Tables 3 and 4 list the different species with their collection site, depth range, abundance and collection number. This collection is deposited in the Royal Belgian Institute for Natural Sciences, in Brussels, Belgium. Most of the identifications are based on the key provided by Clark \& Rowe (1971) for the echinoids and on the keys provided by Cherbonnier (1988) for the holothurians. 
Table 2. Littoral Holothuroidea and Echinoidea from the Kiunga Marine Reserve and surrounding regions (recent records only): (1) Tortonese, 1980 (Somalia); (2) Tortonese, 1951 (Somalia); (3) Tortonese, $1949-51$ (Somalia); (4) Levin, 1979 (Mombasa, Kenya); (5) Humphreys, 1981 (Kenya and adjacent regions); (6) Obura et al., 1998 (Kiunga Marine Reserve); (7) this study. ${ }^{* *}$ denotes a new record for the Indian Ocean; * denotes a new record for Kenya.

\begin{tabular}{|c|c|c|c|c|c|c|c|c|}
\hline Current species name & 1 & 2 & 3 & 4 & 5 & 6 & 7 & \\
\hline \multicolumn{9}{|l|}{$\begin{array}{l}\text { ECHINOIDEA } \\
\text { IRREGULARIA } \\
\text { Brissidae }\end{array}$} \\
\hline Brissus latecarinatus (Leske, 1778) & & & & & $x$ & & & \\
\hline Metalia sternalis (Lamarck, 1816) & & & & & $\hat{x}$ & & & \\
\hline \multicolumn{9}{|l|}{$\begin{array}{l}\text { Clypeasteridae } \\
\end{array}$} \\
\hline Clypeaster fervens Koehler, 1922 & & & & & $x$ & & \multirow{3}{*}{$\mathrm{x}$} & \multirow{4}{*}{ * } \\
\hline Clypeaster rarispinus de Meijere, 1902 & & & & & $x$ & & & \\
\hline $\begin{array}{l}\text { Clypeaster reticulatus (Linnaeus, 1758) } \\
\text { Echinoneidae }\end{array}$ & & & & & $x$ & & & \\
\hline $\begin{array}{l}\text { Echinoneus cyclostomus Leske, } 1778 \\
\text { Laganidae }\end{array}$ & $x$ & & & & $x$ & & & \\
\hline Laganum depressum Lesson in L. Agassiz, 1841 & $x$ & $\mathrm{x}$ & & & $x$ & & $x$ & \\
\hline Laganum joubini Koehler, 1922 & & & & & $x$ & & & \\
\hline $\begin{array}{l}\text { Schizasteridae } \\
\text { Schizasterid sp. }\end{array}$ & & & & & $\mathbf{x}$ & & & \\
\hline Spatangidae & & & & & $x$ & & & \\
\hline Maretia planulata (Lamarck, 1816) & & & & & $x$ & & & \\
\hline Scutellidae & & & & & & & & \\
\hline $\begin{array}{l}\text { Echinodiscus bisperforatus Leske, } 1778 \\
\quad \text { cited as Echinodiscus biforis (Gmel.) } \\
\text { REGULARIA } \\
\text { Cidaridae }\end{array}$ & & & & & $x$ & & $x$ & \\
\hline Eucidaris metularia (Lamarck, 1816) & $x$ & & & & $\mathbf{x}$ & & & \\
\hline Prionocidaris baculosa (Lamarck, 1816) & & & & & $x$ & & & \\
\hline Prionocidaris verticillata (Lamarck, 1816) & & & & & $x$ & & & \\
\hline $\begin{array}{l}\text { Phyllacanthus imperialis (Lamarck, 1816) } \\
\text { Diadematidae }\end{array}$ & & & & & & & $x$ & ״ \\
\hline Astropyga radiata (Leske, 1778) & & & & & $\mathbf{x}$ & & $\mathbf{x}$ & \\
\hline Diadema savignyi Michelin, 1845 & & & & & $x$ & & $\mathbf{x}$ & \\
\hline Diadema setosum (Leske, 1778) & & & & & $\mathbf{x}$ & $\mathbf{x}$ & $x$ & \\
\hline Echinothrix diadema (Linnaeus, 1758) & $x$ & & & & $x$ & $x$ & $x$ & \\
\hline $\begin{array}{l}\text { Echinothrix calamaris (Pallas, 1774) } \\
\text { Echinometridae }\end{array}$ & & $\mathbf{x}$ & & & $\mathbf{x}$ & & $\mathbf{x}$ & \\
\hline Colobocentrotus atratus (Linnaeus, 1758) & & & $\mathrm{x}$ & & $x$ & & & \\
\hline Echinometra mathaei (de Blainville, 1825) & $x$ & $x$ & & & $\ddot{x}$ & $\mathbf{x}$ & $\mathbf{x}$ & \\
\hline cited as $E$. mathaei violacea & & & $\mathrm{x}$ & & & & & \\
\hline Echinostrephus molaris (de Blainville, 1825) & & & & & $\mathrm{x}$ & $x$ & $x$ & \\
\hline Heterocentrotus mammillatus (Linnaeus, 1758 ) & & & & & $\mathrm{x}$ & & $x$ & \\
\hline $\begin{array}{l}\text { Heterocentrotus trigonarius (Lamarck, 1816) } \\
\text { Stomopneustidae }\end{array}$ & & & $x$ & & $x$ & & & \\
\hline $\begin{array}{l}\text { Stomopneustes variolaris (Lamarck, 1816) } \\
\text { Parasalenidae }\end{array}$ & $x$ & $x$ & & & $x$ & $x$ & $\mathbf{x}$ & \\
\hline Parasalenia gratiosa A. Agassiz, 1863 & & & & & $\mathbf{x}$ & & & \\
\hline Temnopleuridae & & & & & & & & \\
\hline Microcyphus rousseaui L. Agassiz, 1846 & $\mathbf{x}$ & & & & & & $\mathbf{x}$ & * \\
\hline $\begin{array}{l}\text { Salmacis bicolor in Agassiz \& Désor, } 1846 \\
\text { Toxopneustidae }\end{array}$ & & $\mathbf{x}$ & & & & & & \\
\hline Toxopneustes pileolus (Lamarck, 1816) & $\mathbf{x}$ & $x$ & & & $x$ & $x$ & $\mathbf{x}$ & \\
\hline $\begin{array}{l}\text { Tripneustes gratilla (Linnaeus, 1758) } \\
\text { HOLOTHUROIDEA } \\
\text { Holothuridae }\end{array}$ & $x$ & $\mathrm{x}$ & $x$ & & $x$ & $x$ & $x$ & \\
\hline Actinopyga echinites (Jaeger, 1833) & $\mathrm{x}$ & & & & & & $\mathbf{x}$ & \\
\hline cited as A. plebeja & & & & $x$ & & & & \\
\hline Actinopyga lecanora (Jaeger, 1833) & & & & $\mathrm{x}$ & & & & \\
\hline Actinopyga mauritiana (Quoy \& Gaimard, 1833) & $x$ & & & & $x$ & $x$ & $x$ & \\
\hline Actinopyga miliaris (Quoy \& Gaimard, 1833) & & & & $x$ & $x$ & & $x$ & \\
\hline cited as Actinopyga sp. & & & & & & $x$ & & \\
\hline Actinopyga sp. & & & & & $x$ & & & \\
\hline Bohadschia atra Massin et al., 1999 & & & & & & & $\mathbf{x}$ & \\
\hline
\end{tabular}




\begin{tabular}{|c|c|c|c|c|c|c|c|c|}
\hline Current species name & 1 & 2 & 3 & 4 & 5 & 6 & 7 & \\
\hline $\begin{array}{l}\text { Bohadschia subrubra (Quoy \& Gaimard, 1833) } \\
\text { cited as Bohadschia koellikeri (Semper. 1868) }\end{array}$ & & & & & & $x$ & $\mathbf{x}$ & \\
\hline $\begin{array}{l}\text { cited as Bohadschia koellikeri (Semper, 1868) } \\
\text { Bohadschia vitiensis (Semper, 1868) }\end{array}$ & & & & & $x$ & $x$ & & \\
\hline Bohadschia marmorata Jaeger, 1833 & & & & $\mathbf{x}$ & $\mathrm{x}$ & & $\mathrm{x}$ & \\
\hline $\begin{array}{l}\text { Holothuria (Acanthotrapeza) pyxis Selenka, } 1867 \\
\text { Holothuria (Cystipus) rigida (Selenka, 1867) }\end{array}$ & & & & $x$ & & & $\mathbf{x}$ & * \\
\hline Holothuria (Halodeima) atra Jaeger, 1833 & $\mathbf{x}$ & & & & $\mathrm{x}$ & $\mathbf{x}$ & $\mathbf{x}$ & \\
\hline Holothuria (Halodeima) edulis Lesson, 1830 & & & & & & $\hat{x}$ & $\mathrm{x}$ & \\
\hline Holothuria (Lessonothuria) pardalis Selenka, 1867 & $x$ & & & & $\mathrm{x}$ & & $\mathrm{x}$ & \\
\hline Holothuria (Mertensiothuria) leucospilota (Brandt, 1835) & $x$ & & & & $x$ & & $x$ & \\
\hline Holothuria (Metriatyla) scabra Jaeger, 1833 & & & & & $\mathrm{x}$ & $\mathrm{x}$ & $\mathrm{x}$ & \\
\hline $\begin{array}{l}\text { Holothuria (Microthele) nobilis (Selenka, 1867) } \\
\text { Holothuria (Platyperona) difficilis Semper, } 1868 \\
\text { Holothuria (Platyperona) strigosa Selenka, } 1867\end{array}$ & $\mathbf{x}$ & & & & $\mathrm{x}$ & 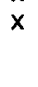 & $\ddot{x}$ & * \\
\hline cited as Holothuria (Thymiosycia) strigosa & $\mathbf{x}$ & & & & & & & \\
\hline Holothuria (Semperothuria) cinerascens (Brandt, 1835) & $x$ & & & $\mathrm{x}$ & $x$ & & $\mathbf{x}$ & \\
\hline $\begin{array}{l}\text { Holothuria (Selenkothuria) erinaceus Semper, } 1868 \\
\text { Holothuria (Selenkothuria) parva Lampert, } 1885\end{array}$ & $\begin{array}{l}x \\
x\end{array}$ & & & & & $x$ & & \\
\hline Holothuria (Stauropora) fuscocinerea Jaeger, 1833 & & & & & $\mathrm{x}$ & & $\mathbf{x}$ & \\
\hline $\begin{array}{l}\text { Holothuria (Stauropora) pervicax Selenka, } 1867 \\
\text { Holothuria (Theelothuria) turriscelsa Cherbonnier, } 1980\end{array}$ & $\mathrm{x}$ & & & & $x$ & & $x$ & \\
\hline Holothuria (Thymiosycia) arenicola Semper, 1868 & $x$ & & & & & & $\mathrm{x}$ & * \\
\hline Holothuria (Thymiosycia) hilla Lesson, 1830 & $\hat{x}$ & & & & $\mathbf{x}$ & & $\hat{x}$ & \\
\hline Holothuria (Thymiosycia) impatiens (Forskål, 1775) & $x$ & & & & $x$ & & $\mathbf{x}$ & \\
\hline $\begin{array}{l}\text { Labidodemas rugosum (Ludwig, 1875) } \\
\text { Labidodemas pertinax Ludwig, } 1875\end{array}$ & $x$ & & & & & & $x$ & * \\
\hline $\begin{array}{l}\text { Labidodemas semperianum Selenka, } 1867 \\
\text { Stichopodidae }\end{array}$ & & & & & $x$ & & & \\
\hline $\begin{array}{l}\text { Stichopus chloronotus Brandt, } 1835 \\
\text { Stichopus herrmanni Semper, } 1868\end{array}$ & & & & & & & $\begin{array}{l}x \\
x\end{array}$ & * \\
\hline cited as Stichopus variegatus Semper, 1868 & & & & $x$ & $\mathrm{x}$ & & & \\
\hline $\begin{array}{l}\text { Stichopus monotuberculatus (Quoy \& Gaimard, 1833) } \\
\text { cited as Stichodactylidae so } 1\end{array}$ & & & & & & & $x$ & * \\
\hline $\begin{array}{l}\text { cited as Stichodactylidae sp. } 1 \\
\text { Thelenota ananas (Jaeger, 1833) } \\
\text { Phyllophoridae }\end{array}$ & & & & & $\mathrm{x}$ & $\mathrm{x}$ & & \\
\hline Afrocucumis africana (Semper, 1868) & $x$ & & & & $\mathbf{x}$ & & $\mathrm{x}$ & \\
\hline $\begin{array}{l}\text { Chiridotidae } \\
\text { Polycheira fusca (Quoy \& Gaimard, 1833) }\end{array}$ & & & & & & & & \\
\hline $\begin{array}{l}\text { cited as Polycheira rufescens (Brandt, 1835) } \\
\text { Synaptidae }\end{array}$ & $\mathrm{x}$ & & & & & & & \\
\hline Opheodesoma spectabilis Fischer, 1907 & & & & & & & & \\
\hline $\begin{array}{l}\text { cited as Opheodesoma sp. prob. O. spectabilis Fischer, } 1907 \\
\text { Synapta maculata (Chamisso \& Eysenhardt, 1821) }\end{array}$ & & & & & $\begin{array}{l}x \\
x\end{array}$ & & $\mathrm{x}$ & \\
\hline
\end{tabular}

\section{ECHINOIDEA (Local Swahili name: urumba)}

We collected 34 specimens, representing 14 species of Echinoidea. No specimens were collected for two species that were reliably identified in the field: Astropyga radiata and Heterocentrotus mammillatus. According to literature, four more species, Colobocentrotus atratus, Echinoneus cyclostomus, Eucidaris metularia and Heterocentrotus trigonarius are expected in the studied region. This would bring the total echinoid fauna of the Kiunga Marine Reserve to 20 species; three of these are reported here for the first time from Kenya: Clypeaster rarispinus, Phyllacanthus imperialis and Microcyphus rousseaui.

Order Clypeasteroidea L. Agassiz \& Desor, 1847

Family Clypeasteridae L. Agassiz, 1881

Genus Clypeaster Lamarck, 1801

Clypeaster rarispinus de Meijere, 1902. Pl. 1A

Material examined. KKiun/9916 (four specimens). 
Table 3. List of echinoids collected at the different localities in the Kiunga Marine Reserve. The number of specimens refers to the number of animals that were encountered during a 60 minute sampling period. i.t. stands for intertidal. Depths apply to the low water level.

\begin{tabular}{|c|c|c|c|c|}
\hline Species & Site name & $\begin{array}{l}\text { Min -max } \\
\operatorname{depth}(m)\end{array}$ & Approx \# & Collection number \\
\hline \multicolumn{5}{|l|}{$\begin{array}{l}\text { IREGULARIA } \\
\text { Clypeasteridae }\end{array}$} \\
\hline Clypeaster ranispinus & Mkomani & i.t. & No data & KKiun/9916 \\
\hline Laganum depressum & Mikomani & i.t. & No data & KKiun/9917 \\
\hline $\begin{array}{l}\text { Echinodiscus bisperforatus } \\
\text { REGULARIA }\end{array}$ & Mkomani & i.t. & No data & KKiun/9915 \\
\hline & Kilima Nungu & 5 & 1 & KKiun/9901 \\
\hline $\begin{array}{l}\text { Dladematidae } \\
\text { Astropyga radiata }\end{array}$ & Mlango Bomani & 2 & 1 & None \\
\hline Diadema savignyi & $\begin{array}{l}\text { Mkomani } \\
\text { Mwamba Mkuu } \\
\text { Kaddhika } \\
\text { Hindi }\end{array}$ & $\begin{array}{l}\text { i.t. } \\
9 \\
1 \\
1\end{array}$ & $\begin{array}{l}2 \\
1 \\
2 \\
2\end{array}$ & $\begin{array}{c}\text { None } \\
\text { None } \\
\text { None } \\
\text { KKiun/9903 }\end{array}$ \\
\hline Diadema setosum & $\begin{array}{l}\text { Shimo La Tewa } \\
\text { Chongo Cha Kui } \\
\text { Kui }\end{array}$ & $\begin{array}{c}3-7 \\
8 \\
3\end{array}$ & $\begin{array}{l}3 \\
1 \\
1\end{array}$ & $\begin{array}{l}\text { None } \\
\text { None } \\
\text { KKiun/9902 }\end{array}$ \\
\hline Echinothrix calamaris & Kaddhika & 2 & 1 & KKiun/9905 \\
\hline Echinothrix diadema & $\begin{array}{l}\text { Mwamba Mkuu } \\
\text { Mlango wa Bomani } \\
\text { Kaddhika } \\
\text { Mwamba wa Boso } \\
\text { Hindi }\end{array}$ & $\begin{array}{l}10-12 \\
1-3 \\
1-3 \\
1-3 \\
1-3\end{array}$ & $\begin{array}{l}2 \\
10 \\
6 \\
8 \\
5\end{array}$ & $\begin{array}{l}\text { KKiun/9904 } \\
\text { None } \\
\text { None } \\
\text { None } \\
\text { None }\end{array}$ \\
\hline $\begin{array}{l}\text { Echinometridae } \\
\text { Echinometra mathaei }\end{array}$ & Mkomani & i.t. & 10 & KKiun/9913 \\
\hline & $\begin{array}{l}\text { Kui } \\
\text { Mwamba Mkuu } \\
\text { Mlango wa Bomani } \\
\text { Kaddhika } \\
\text { Mwamba wa Boso } \\
\text { Chongo cha Chano }\end{array}$ & $\begin{array}{c}2-4 \\
9-10 \\
1-3 \\
1-2 \\
1 \\
10\end{array}$ & $\begin{array}{c}1 \\
2 \\
10 \\
10 \\
1 \\
1 \\
1\end{array}$ & $\begin{array}{l}\text { None } \\
\text { None } \\
\text { None } \\
\text { None } \\
\text { None } \\
\text { None }\end{array}$ \\
\hline Echinostrephus molaris & $\begin{array}{l}\text { Mkomani } \\
\text { Mwamba Mkuu } \\
\text { Mlango wa Bomani } \\
\text { Wreck } \\
\text { Kiunga Camp } \\
\text { Chongo cha } \\
\text { Mvundeni }\end{array}$ & $\begin{array}{c}10 \\
2 \\
7-17 \\
2-4 \\
6-10 \\
1-7 \\
14-27\end{array}$ & $\begin{array}{c}2 \\
>100 \\
>50 \\
15 \\
20 \\
>30\end{array}$ & $\begin{array}{l}\text { KKiun/9914 } \\
\text { None } \\
\text { None } \\
\text { None } \\
\text { None } \\
\text { None }\end{array}$ \\
\hline & $\begin{array}{l}\text { Chongo cha Chano } \\
\text { Mike's Outer Reef }\end{array}$ & $\begin{array}{l}9-13 \\
1-2\end{array}$ & $\begin{array}{l}3 \\
3\end{array}$ & $\begin{array}{l}\text { None } \\
\text { None }\end{array}$ \\
\hline $\begin{array}{l}\text { Heterocentrotus } \\
\text { mammillatus } \\
\text { Stomopneustidae }\end{array}$ & Mlango wa Bomani & $2-5$ & 1 & None \\
\hline Stomopneustes variolaris & $\begin{array}{l}\text { Mkomani } \\
\text { Mlango wa Bomani } \\
\text { Kiunga Camp } \\
\text { Hindi } \\
\text { Kilima Nungu }\end{array}$ & $\begin{array}{l}1-2 \\
1-3 \\
1-7 \\
2 \\
4-8\end{array}$ & $\begin{array}{c}>100 \\
>50 \\
>20 \\
1 \\
5\end{array}$ & $\begin{array}{c}\text { KKiun/9910 } \\
\text { None } \\
\text { None } \\
\text { None } \\
\text { None }\end{array}$ \\
\hline $\begin{array}{l}\text { Temnopleuridae } \\
\text { Microcyphus rousseaui }\end{array}$ & $\begin{array}{l}\text { Kiunga Camp } \\
\text { Chongo cha Mvuendi }\end{array}$ & $\begin{array}{l}7 \\
17\end{array}$ & $\begin{array}{l}1 \\
1\end{array}$ & $\begin{array}{l}\text { KKiun/9906 } \\
\text { KKiun/9907 }\end{array}$ \\
\hline $\begin{array}{l}\text { Toxopneustidae } \\
\text { Toxopneustes pileolus }\end{array}$ & $\begin{array}{l}\text { Mlango wa Bomani } \\
\text { Mwamba wa Boso }\end{array}$ & $\begin{array}{l}1-5 \\
1-2\end{array}$ & $\begin{array}{l}1 \\
3 \\
2\end{array}$ & $\begin{array}{l}\text { None } \\
\text { None }\end{array}$ \\
\hline Tripneustes gratilla & $\begin{array}{l}\text { Hindi } \\
\text { Mlango wa Bomani } \\
\text { Kaddhika } \\
\text { Mike's Outer Reef } \\
\text { Hindi }\end{array}$ & $\begin{array}{c}1 \\
1-2 \\
1-2 \\
2 \\
1.5\end{array}$ & $\begin{array}{c}2 \\
>50 \\
2 \\
1 \\
1\end{array}$ & $\begin{array}{l}\text { KKiun/9911 } \\
\text { KKiun/9912 } \\
\text { None } \\
\text { KKiun/9908 } \\
\text { KKiun/9909 }\end{array}$ \\
\hline
\end{tabular}


Taxonomic description. See Mortensen, 1948: 58-62, figure 43, pl. 6 figures 1-15, pl. 40 figures 4, 5, 8, 9, pl. 64 figures 11, 12, 14-17, 20 (as Clypeaster (Leptoclypus) rarispinus); Clark \& Rowe, 1971: 160.

Field description. Relatively small species with lengths smaller than $100 \mathrm{~mm}$; flattened and pentagonal body, only slightly raised centrally; five narrow petal areas reaching to about a third of the diameter, periproct hardly separated from the posterior edge; sutures of oral and aboral plates forming a dark reticulum.

Abundance in the Kiunga Marine Park. Probably common, although neither Obura et al. (1998) (KMR), nor Tortonese $(1949,1951,1980)$ (southern Somalia) were able to find it.

Local distribution. Humphreys (1981) failed to find it in Kenya, but dredged it at Tumbatu, Zanzibar Channel. The burrowing behaviour of this species makes it hard to find, so data on abundance are not reliable, and earlier workers might have easily missed it. It is reported here as a first record for Kenya. Russo (1932) and Tortonese (1936) report it from the Red Sea as Clypeaster Audouin; Tortonese (1955) from the Red Sea as Clypeaster (Leptoclypus) rarispinus. Price (1982) reports this species from the Arabian Gulf, SE Arabia, the Red Sea, the Gulf of Aqaba and the Gulf of Suez. Clark \& Rowe (1971) list it as an Indo-Pacific species from East Africa (with the Red Sea) to the East Indies (see also Mortensen, 1948).

\section{Family Laganidae A. Agassiz, 1872 \\ Genus Laganum Gray, 1825}

Laganum depressum Lesson in L. Agassiz, 1841

Material examined. KKiun/9917 (seven specimens).

Taxonomic description. See Mortensen, 1948: 313-318, figure 197, pl. 52 figures 12, 14, pl. 53 figures 3, 4, 6-32, pl. 70, figure 20; Clark \& Rowe, 1971: 162; figure 77, p. 162; pl. 25 figure 10.

Field description. Flattened, elliptical body with test length up to $40 \mathrm{~mm}$, with rather thick margins and well developed petals reaching up to the thickened margin; five clearly visible pores; periproct nearer to the posterior edge than to the mouth.

Abundance in the Kiunga Marine Park. Probably common. Due to its burrowing behaviour this species is easily overlooked, so data on abundance are not reliable.

Local distribution. Humphreys (1981) found it earlier in Kenya (Watamu Marine Park, north Kilifi, Malindi), Tortonese $(1951,1980$ ) in Somalia (unspecified and Sar Uanle, $20 \mathrm{~km}$ south of Kismayu). Ludwig (1899) was the first to report it from East Africa (Zanzibar). Clark \& Rowe (1971) list it as an Indo-Pacific species from East Africa (with the Red Sea) to the Islands of the South-Pacific (see also Mortensen, 1948; Rowe \& Richmond, 1997).

\section{Family Scutellidae Gray, 1825 \\ Genus Echinodiscus Leske, 1778}

Echinodiscus bisperforatus Leske, 1778

Material examined. KKiun/9915 (one specimen). This sample was fragmented during transport to Belgium, our field description is completely similar to Mortensen's (1948).

Taxonomic description. See Mortensen, 1948: 406-411, figures 241a, 242a, b, pl. 58 figures 2, 6-8, pl. 71 figures 6-9, 18; Clark \& Rowe, 1971: 162; pl. 25 figure 9.

Field description. Test length up to $130 \mathrm{~mm}$, flattened body with posteriorly two distinct closed lunules in the posterior paired ambulacra, at least as long as the petals; body covered with fine spines, on the oral side forming a distinct pattern in the ambulacral areas. 
Abundance in the Kiunga Marine Park. Abundant, however we collected only one specimen, which was unfortunately fragmented during transport. Not reported by Obura $e t$ al. (1998) from the Kiunga Marine Reserve; J. Church reports on the species as being abundant in the Kiunga Marine Reserve (pers. comm.).

Local distribution. Tortonese $(1949,1951,1980)$ failed to find it in Somalia, he reported it earlier from the Red Sea (Tortonese, 1936). Later Price (1982) confirms that record by reporting it from the Red Sea, the Arabian Gulf, SE Arabia, and the Gulf of Suez; Ludwig (1899), Ruwa (1989) and Humphreys (1981) report it from Kenya (Lamu), making the species expected and abundant for the examined region. Lambert (1921-22) also reported it from East Africa (Madagascar) as Tetrodiscus biforis. Echinodiscus bisperforatus ranges geographically from East Africa (with the Red Sea) to the islands of the South Pacific (see also Mortensen, 1948; Clark \& Rowe, 1971; Clark and Courtman-Stock, 1976; Rowe \& Richmond, 1997).

Order Cidaroidea Duncan, 1899

Family Cidaridae Gray, 1825

Genus Phyllacanthus Brandt, 1835

Phyllacanthus imperialis (Lamarck, 1816). P1. 1B

Material examined. KKiun/9901 (one specimen).

Taxonomic description - See Mortensen, 1928: 504-509, figure 163, pl. 54 figure 4, pl. 57 figure 3, pl. 74 figure 6, pl. 88 figure 4-10; Clark \& Rowe, 1971: p. 151; figure 59 b, p. $150 ;$ pl. 23 figure 2.

Field description. Large cidaroid with test diameter up to $100 \mathrm{~mm}$; red primary spines of approximately the same length as the horizontal diameter, smooth, white-grey banded, grooved at their tips; surrounded by short reddish spatulate secondary spines. Apical area 29-34\% of the horizontal diameter with a more or less dense covering of spinelets. Primary spines often with epizoic organisms. Nocturnal foraging behaviour. Naked test: pore-pairs in single series, sunken in a common furrow; apical system with exsert ocular plates and with numerous tubercles; peristomial pores in double rows, zig-zagging; genital pores not elevated.

Abundance in the Kiunga Marine Reserve. Very rare; not reported by Obura et al. (1998); we have seen it twice during night dives (Mkomani and Kilima Nungu).

Local distribution. Reported from Zanzibar by Agassiz (1872, in Ludwig, 1899) as Leiocidaris imperialis. Humphreys (1981) didn't report it from Kenya; Tortonese (1949; $1951 ; 1980$ ) failed to report it in Somalia, making this observation a new record for Kenya. Other important records include those by Hoffman (1874) as Cidaris fustigera and Mortensen (1931) from Madagascar (Tuléar and Nosy Bé); by Lambert (1921-22) as Leiocidaris imperialis from Réunion; by Sloan et al., 1979 from Aldabra and by A.M. Clark (1984) from the Seychelles. Clark \& Rowe (1971) list it as an Indo-Pacific species from East Africa (with the Red Sea) to the East Indies (see also H.L. Clark, 1925; Mortensen, 1928; Rowe \& Richmond, 1997).

\section{Order Aulodonta Jackson, 1912 \\ Family Diadematidae Peters, 1855 $^{1}$}

\footnotetext{
${ }^{1}$ Mortensen (1940) states that Peters, 1855 and not Gray, 1835 (in Mortensen, 1940) or 1855 (in Mortensen, 1940) is the authority for the Diadematidae. This because Gray's paper of 1835 only speaks of the genera Arbacia, Salenia, Echinus and Echinometra; and because Gray's
} 


\section{Genus Astropyga Gray, 1825}

Astropyga radiata (Leske, 1778). P1. 1C

Material examined. Since only one specimen was spotted in the Kiunga Marine Reserve (at Mlango wa Bomani) no sample was taken; identification in the field is certain (see also pl. 1C).

Taxonomic description. See Mortensen, 1940: 187-196, figures 111-115, pl. 8 figure 6, pl. 9 figures 6-9, pls. 10-12 figures 1-2, pl.12 figure 1, pl. 14 figures 1-3, pl. 15 figure 2, pl. 16 figure 1, pl. 17 figure 1, pl. 18 figure 1, pl. 20 figure 4, pl. 70 figures $1-3,7,13-17$, pl. 71 figures 2, 4, 6; Clark \& Rowe, 1971: p. 152; figure 63 a, p. 152; pl. 23 figure 3 (juvenile specimen).

Field description. Large sea urchin, test diameter up to $180 \mathrm{~mm}$. Test with intense red bands bordered by fluorescent blue spots; anus red-brown with white-red spots. Periproct flat or low conical. A large colour variation, from almost white to almost black, exists, but the red cross is always clearly visible. Primary spines black, finely ridged, long, easily breakable, filled with loose meshwork. Naked test: crenulate primary tubercles well developed over the total test surface; pore-pairs arranged in arcs, elongated genital plates.

Abundance in the Kiunga Marine Reserve. Very rare, not observed by Obura et al. (1998) Local distribution. Humphreys (1981) found a single test in the Watamu Marine Park, Tortonese $(1949 ; 1951 ; 1980)$ failed to find it in Somalia. One of us (YS) found it earlier along the Kenyan coastline (in Gazi Bay and in Mombasa). The Kiunga Marine Reserve can however be considered as part of its range, since Price (1982) reports its presence from South East Arabia and several workers recorded it more to the south: Zanzibar (Agassiz, 1872; Pfeffer, 1896), Aldabra (Sloan et al., 1979), Mozambique (Peters, 1854; Bell, 1884) and in the Seychelles (Bell, 1884; Clark, 1984). Its geographical range is the total tropical Indo-Pacific (with the Red Sea) up to Hawaii (see also Mortensen, 1940; Clark \& Rowe, 1971; Clark \& Courtman-Stock, 1976; Rowe \& Richmond, 1997).

\section{Genus Diadema Humphreys, 1797}

\section{Diadema savignyi Michelin, 1845}

Material examined. KKiun/9903 (two specimens: one adult and one juvenile).

Taxonomic description - See Mortensen, 1940: 265-269, figures 136, 141b, 143, pl. 48 figure 1, pl. 49 figure 4 , pl. 52 figures $1-2$, pl. 53 figures $2-5$, pl. 59 figure $1-12$, pl. 60 figures 4-6, pl. 74 figures 10-14, 16, 19; Clark \& Rowe, 1971: p. 153.

Field description. Small-bodied sea urchin (horizontal test diameter max $50 \mathrm{~mm}$ ) with long (up to $100 \mathrm{~mm}$ ), slender, fragile (hollow), finely ridged, black or grey primary spines, which can be white-banded (especially prominent in juveniles); no orange ring around tip of the anal cone, iridescent blue lines around the periproct and down the interambulacra; buccal plates spineless. Naked test: total surface with well-developed primary perforate and crenulate tubercles (decreasing in size towards the peristome); triplet of pore-pairs arranged in arcs for each primary tubercle; genital plates not longer then wide; length-breadth test usually 4-5:1.

paper of 1855 speaks of the Diademadae [sic] (however with a correct description of the family in question). Peters, 1855 speaks of the Diadematiden (with a correct description of the family, however without using a scientific, Latinised name) and read his paper in 1853 , i.e. well before Gray. 
Abundance in the Kiunga Marine Reserve. Common, however not reported by Obura et al. (1998) from the Kiunga Marine Reserve.

Local distribution. Documented as well distributed by Humphreys (1981) from Kenya (Watamu and Malindi Marine Park), however not reported from Somalia (Tortonese, 1949; 1951 ; 1980). Tortonese (1936) reports it as Diadema Savignyi from the Red Sea and Price (1982) reports it further south from South-East Arabia making the Kiunga Marine Reserve part of its range. Even more to the south an important local record is that by Décary (1924) as Diadema Savignyi from Madagascar. Clark \& Rowe (1971) list it as a tropical IndoPacific species from East Africa (without the Red sea) to the Islands of the South Pacific, however not found on Hawaii (see also Mortensen, 1940; Clark \& Courtman-Stock, 1976; Rowe \& Richmond, 1997).

Diadema setosum (Leske, 1778)

Material examined KKiun/9902 (one specimen).

Taxonomic description. See Mortensen, 1940: 256-264, figures 140, 141a, pl. 49 figures $1-2$, pls. $50,51,52$ figure 3, pl. 53 figure 1, pl. 54 figures 2-3, pl. 55 figure 1-6, pl. 56 figures $1-13$, pl. 60 figures 1-2, pl. 61 figure 1, pl. 73 figures 1, 10-12, pl. 74 figures 15, 17, 18, 20; see Clark \& Rowe, 1971: p. 153; figure 62, p. 152; figure 64 b, p. 153; pl. 24 figure 1 .

Field description. Small-bodied sea urchin with approximately the same horizontal diameter as $D$. savignyi, with long (up to $100 \mathrm{~mm}$ ), slender, fragile needle-sharp, black primary spines, which can be banded (especially prominent in juveniles); five white spots on interambulacra, a clear orange ring around the tip of the anal cone; buccal plates without spines. Naked test: very similar to $D$. savignyi but compound plates (pore-pairs no longer correspond to the number of pore triplets) already present in individuals of ca. $40 \mathrm{~mm}$ horizontal diameter (see also figures 140 and 143 in Mortensen, 1940).

Abundance in the Kiunga Marine Reserve. Common, also reported by Obura et al. (1998) from the Kiunga Marine Reserve.

Local distribution. Reported by Humphreys (1981) from Mida Creek and from the Watamu Marine Park, Kenya; not found in Somalia by Tortonese $(1949,1951,1980)$, but documented further north by Price $(1981,1982)$. Other important records include those by Peters (1854) from Mozambique; by Ludwig (1899) from Zanzibar (Ludwig, 1899 also lists older records from the region); by Haacke (1880) from Mauritius, and by Lambert (1921-22) as Centrostephanus setosum from Madagascar. Clark \& Rowe (1971) list it as a tropical Indo-Pacific species from East Africa (with the Red Sea, see also Tortonese, 1936, 1955) to the Islands of the South Pacific, however not on Hawaii (see also Mortensen, 1940; Clark \& Courtman-Stock, 1976; Rowe \& Richmond, 1997).

\section{Genus Echinothrix Peters, 1853}

Echinothrix calamaris (Pallas, 1774)

Material examined. KKiun/9905 (one specimen).

Taxonomic description. See Mortensen, 1940: 285-290, figures 147-149, pl. 39 figure 1, pl. 40 , pl. 41 figures 1-2, pl. 42 figures 1-5, pl. 43 figure 3, pl. 44 figures 2-10, pl. 46 figure 1, pl. 47 figures 1-3, 5, pl. 48 figure 3, pl. 71 figures 5-8; Clark \& Rowe, 1971: 153; figure $63 \mathrm{~b}$, p. 152 ; pl. 31 figure 17.

Field description. Small-bodied (horizontal test diameter up to $85 \mathrm{~mm}$ ) very dark-green to black echinoid with aborally long, barbed, needle-like primary spines. Primary spines 
relatively firm, but with a large central cavity. Both the primary and the very fine secondary spines are often banded with green (especially prominent in juveniles); periproct spotted. Ambulacra bulging aborally with apically naked interambulacra. Naked test: usually greenish in colour; primary tubercles perforated and crenulated, similar over total test surface; genital plates approximately as long as wide.

Abundance in the Kiunga Marine Reserve. Rare, only observed in one locality (Kaddhika). Not reported by Obura et al. (1998) from the Kiunga Marine Reserve.

Local distribution. Humphreys (1981) reports this species from several localities in Kenya, Tortonese $(1949 ; 1951,1980)$ failed to find it in the littoral waters of Somalia; Price (1982), however, reports this species from further afield in SE Arabia, the Red Sea (see also Tortonese, 1955), the Gulf of Aqaba and Suez. Other important historical records for the region include those by Ludwig (1899) as Echinothrix Desori from Zanzibar and by Lambert (1921-22) as Diadema Frappieri from Madagascar. Clark \& Rowe (1971) list it as a tropical Indo-Pacific species from East Africa up to Hawaii (see also Mortensen, 1940; Clark \& Courtman-Stock, 1976; Rowe \& Richmond, 1997).

Echinothrix diadema (Linnaeus, 1758)

Material examined. KKiun/9904 (one specimen).

Taxonomic description. See Mortensen, 1940: 290-295, figures 150-152, pl. 43 figures 12, pl. 44 figure 1, pl. 45 figures 1-8, pl. 46, figures 2-4, pl. 47 figures 4, 6-7, pl. 48 figure 4, pl. 71 figures 1, 3; Clark \& Rowe, 1971: 153; figure 64 a, p. 153; pl. 24 figure 2.

Field description. Large bodied (test diameter up to $140 \mathrm{~mm}$ ) echinoid; all interambulacral plates covered with fine black backwardly-barbed primary spines, dark-reddish test. Ambulacra not distinctively bulging, aborally no naked ambulacral areas. Primary spines very brittle, medium-long (up to $80 \mathrm{~mm}$ ), with narrow central cavity. Naked test: similar to E. calamaris, but mostly larger and never greenish, sometimes reddish.

Abundance in the Kiunga Marine Reserve. Abundant. Reported from the same locality by Obura et al. (1998).

Local distribution. Reported from Kenya by Humphreys (1981) in low numbers in Mida Creek, from southern Somalia (Gesira and Sar Uanle) by Tortonese (1980). Other important historical records for the region include those by Ludwig (1899) as Echinothrix spinosissimum; by Haacke (1880) as E. turcarum from Mauritius; and by Lambert (1921-22) as Diadema turcarum from Madagascar. Clark \& Rowe (1971) list it as a tropical IndoPacific species from East Africa up to Hawaii (see also Mortensen, 1940; Rowe \& Richmond, 1997).

Order Camarodonta Jackson, 1912

Family Echinometridae Gray, 1855

Genus Echinometra Gray, 1825

Echinometra mathaei (de Blainville, 1825)

Material examined. KKiun/9913 (six specimens).

Taxonomic description. See Mortensen, 1943b: 38-3931, figures 185-194, pl. 42 figures 1-10, pl. 47 figures 1-4, pl. 65 figures 16-26; Clark \& Rowe, 1971: p. 157; figure 69 b, p. $156 ; \mathrm{pl} .23$, figure 5 .

Field description. Small sea urchin (test diameter up to $\sim 65 \mathrm{~mm}$ ) with a distinct oval body (when viewed from above) and a high colour variation (from green to brown to purple to black). Fairly long, slender, tapering, stout primary spines, often with a white band at their 
base. Naked test: oval in outline, with long axis of the test through ambulacrum 1 and interambulacrum 3, horizontal test diameter approximately equal to the height of the test; four pore pairs per arc aborally; primary tubercles imperforate; shallow gill slits.

Abundance in the Kiunga Marine Reserve. Abundant; together with Stomopneustes variolaris and Echinostrephus molaris, this species is the most abundant sea urchin in the Kiunga Marine Reserve (see also Obura et al., 1998).

Local distribution. Humphreys (1981) comes to the same conclusion for the Watamu Marine Park and Kilifi. In southern Somalia Tortonese $(1951,1980)$ reports on large populations. Other important historical records for the region include those by Ludwig (1899) as Echinometra lucunter from Zanzibar; by Lambert (1921-22) as Ellipsechinus lukunter from Madagascar. Clark \& Rowe (1971) list it as a tropical Indo-Pacific species (with the Red Sea, see also Tortonese, 1936, 1955) from East Africa up to Hawaii (see also Mortensen, 1943b; Clark \& Courtman-Stock, 1976; Rowe \& Richmond, 1997).

\section{Genus Echinostrephus A. Agassiz, 1863}

Echinostrephus molaris (de Blainville, 1825)

Material examined. KKiun/9914 (one specimen).

Taxonomic description. See Mortensen, 1943b: 311-316, figure 149a, b, figure 150 a, b, pl. 35 figures 1-10, pl. 58 figures 1, 2, 4, 9; Clark \& Rowe, 1971: p. 157.

Field description. Small species with test diameter seldom larger than $30 \mathrm{~mm}$. Test broadest at the flattened aboral side. Always in self-made deep rocky burrows, aboral side flat, with a vertically projecting tuft of long, easily breakable primary spines with variable colouration (whitish-blue to black). Naked test: shallow gill slits; test flattened aborally; invariably three pore-pairs in each arc.

Abundance in the Kiunga Marine Reserve. Abundant, also reported by Obura et al. (1998) from the Kiunga Marine Reserve.

Local distribution. Previously reported from Kenya as common by Humphreys (1981); however never recorded from the Somalian coast; reported from the Red Sea, the Gulf of Aqaba and the Arabian Gulf but not from South East Arabia (Price, 1982). Further south Agassiz (1872, in Ludwig, 1899) lists records from Zanzibar and Mozambique; Bell (1903) from Zanzibar as Echinostrephus molare. Clark \& Rowe (1971) list it as a tropical IndoPacific species from East Africa to the Islands of the South Pacific (see also Mortensen, 1943b; Clark \& Courtman-Stock, 1976; Rowe \& Richmond, 1997).

Plate 1. A. Clypeaster rarispinus de Meijere, 1902; B. Phyllacanthus imperialis (Lamarck, 1816); C. Astropyga radiata (Leske, 1778); $D$. Heterocentrotus mammillatus (Linnaeus, 1758); $E$. Microcyphus rousseaui L. Agassia, 1846; F. Actinopyga echinites (Jaeger, 1833); G. Bohadschia subrubra (Quoy \& Gaimard, 1833); H. Holothuria (Cystipus) rigida (Selenka, 1867). All pictures by Y. Samyn except A. (F. Bossuyt); B. (J. Church) and D. (B. Van Bogaert). 

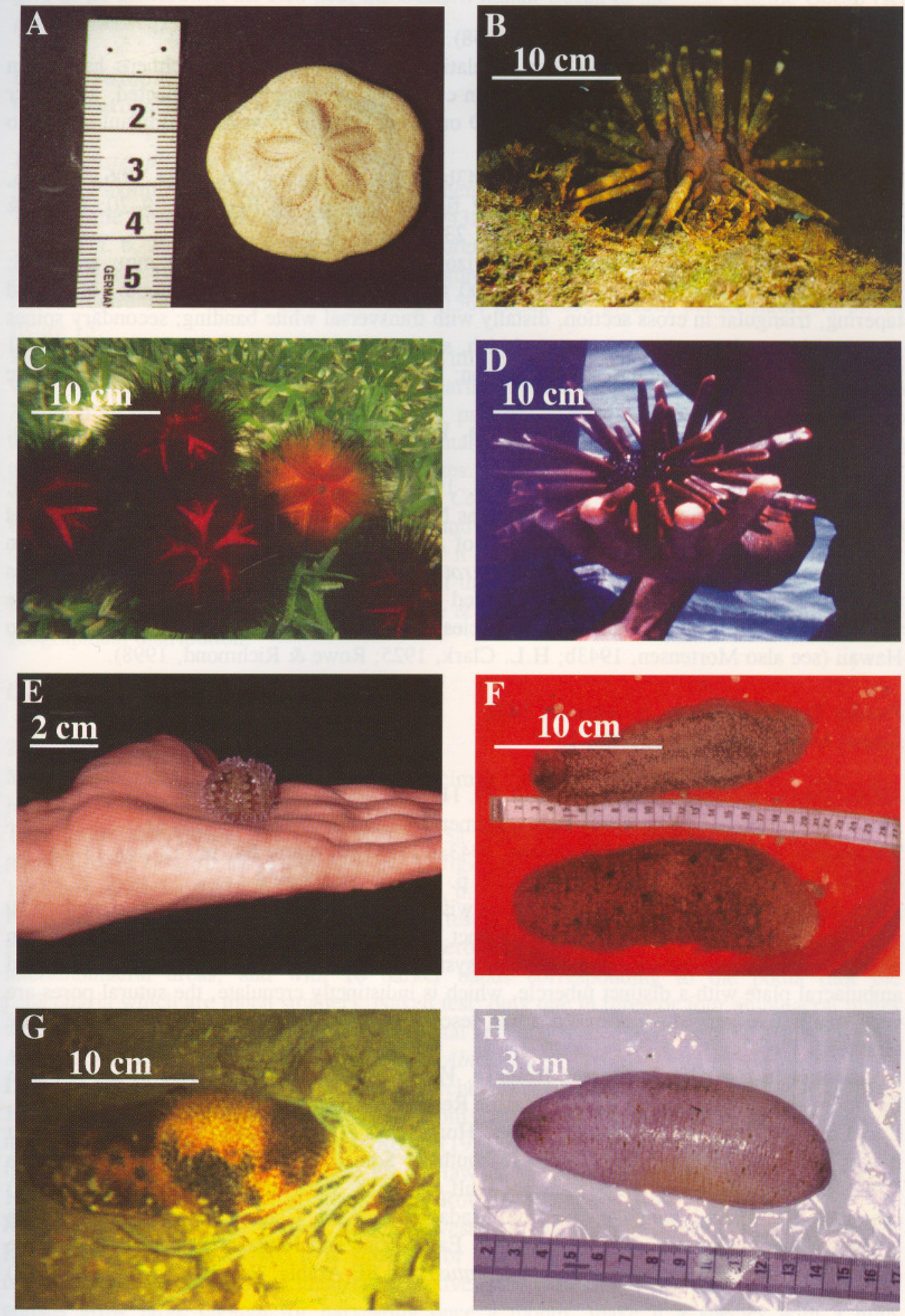


\section{Genus Heterocentrotus Brandt, 1835}

Heterocentrotus mammillatus (Linnaeus, 1758). Pl. 1D

Material examined - Due to its low population numbers (only few specimens have been seen by one of us, YS, over the total Kenyan coastline), no sample was collected. Moreover identification in the field is certain; picture D on pl. 1, taken at Mlango wa Bomani leaves no doubt over the identification.

Taxonomic description. See Mortensen 1943b: 409-420, figures 204, 205a, 206, 207a, b, 208a, 209, 210, pl. 51 figures 1-6, pl. 52 figures 6-8, pl. 66 figures 7, 9-20; Clark \& Rowe, 1971: p. 158; figure 71 b, p. 153; pl. 23 figure 4.

Field description. Large species with horizontal test diameter up to $80 \mathrm{~mm}$; test oval; massive primary spines are long (up to $100 \mathrm{~mm}$ at the ambital side), smooth, blunt and tapering, triangular in cross section, distally with transversal white banding; secondary spines distributed over the total test surface, whitish, short and with flattened tips. Naked test: 9-11 pore-pairs in each arc at the ambital region; primary ambulacral tubercles smaller above ambitus.

Abundance in the Kiunga Marine Reserve. Very rare to Rare, only observed once by us; not reported by Obura et al. (1998).

Local distribution. Tortonese $(1949 ; 1951,1980)$ failed to record it in Somalian waters; Humphreys (1981) reports it from Kenya (Ras Ngomeni); Price reports from SE Arabia, Red Sea (see also Tortonese, 1955) and the Gulf of Aqaba; Haacke (1880) from Mauritius. Given these records and the fact that Heterocentrotus mammillatus is nocturnal this species is probably more abundant than what is deduced from our observations. A.M. Clark \& Rowe (1971) list it as a tropical Indo-Pacific species from East Africa (with the Red Sea) up to Hawaii (see also Mortensen, 1943b; H.L. Clark, 1925; Rowe \& Richmond, 1998).

Family Temnopleuridae A. Agassiz, 1872

Genus Microcyphus L. Agassiz, 1841

Microcyphus rousseaui L. Agassiz, 1846. Pl. 1E

Material examined. KKiun/9906 (one specimen); KKiun/9907 (one specimen).

Taxonomic description. See Mortensen, 1943a: 155-159, figure 84, pl. 12 figs 18-25, pl. 47 figs 18-20, 23-24; Clark \& Rowe, 1971: p. 156; pl. 24 figure 6.

Field description - Relatively small species with horizontal test diameter rarely exceeding 50 mm. Naked, dark purple areas with a distinct whitish-pink zigzag line; spines beige-brown with distinct darker brown bands. Apical system rounded. Naked test: each ambital and ambulacral plate with a distinct tubercle, which is indistinctly crenulate, the sutural pores are very small; five very distinct naked areas descending from the aboral side over almost the total test

Abundance in the Kiunga Marine Reserve. Very rare, only observed twice by us, not seen by Obura et al. (1998) in the Kiunga Marine Reserve.

Local distribution. First record for Kenya. Humphreys (1981) failed to find it in Kenya, but it was observed by Tortonese (1980) in southern Somalia (Gesira). Also found by Price (1982) in SE Arabia, the Red Sea and the Gulf of Aqaba. Further South, Lambert (1921-22) describes it as Microcyphus Decaryi from Madagascar, A.M. Clark \& Rowe (1971) list it as a tropical Indian Ocean species restricted to East Africa and Madagascar, the Red Sea (see also Tortonese, 1936 as Microcyphus maculatus) and SE Arabia. Rowe \& Richmond (1997) 
give as its distribution the Red Sea, the western Indian Ocean to the West Pacific Ocean (see also Mortensen, 1943a).

\section{Family Toxopneustidae Trosschel, 1872 \\ Genus Toxopneustes L. Agassiz, 1841}

Toxopneustes pileolus (Lamarck, 1816)

Material examined. KKiun/9911 (one specimen).

Taxonomic description. See Mortensen, 1943a: 472-480, figures 240b, 293a, 294, 295a, 296, 297a, b, 298, pl. 26 figure 3, pl. 27 figures 1-4, pl. 28 figures 1, 2, pl. 29 figures 1-5, pl. 30 figures 1-4, pl. 31 figure 9, pl. 33 figures 5, 6, pl. 54 figures 1, 3-6, 8-10, 13-16, pl. 55 figure 13; Clark \& Rowe, 1971: p. 156; figure 69, p. 156; pl. 24 figure 7; pl. 31 figure 15 .

Field description. Large-bodied sea urchin with low test (horizontal diameter up to $150 \mathrm{~mm}$; with very large, orange, globiferous pedicellariae (diameter up to $3 \mathrm{~mm}$ ); very short (up to $20 \mathrm{~mm}$ ) orange, finely-ridged longitudinal primary spines. Naked test: usually sunken towards the mouth; purple banded horizontally; every second ambulacral plate with a primary tubercle; oligoporous ambulacral plates.

Abundance in the Kiunga Marine Reserve. Common.

Local distribution. This species has been found by almost all the researchers that sampled in this region. A.M. Clark \& Rowe (1971) list it as a tropical Indo-Pacific species from East Africa (without the Red Sea) to the Islands of the South Pacific (see also Mortensen, 1943a; A.M. Clark \& Courtman-Stock, 1976). Rowe \& Richmond (1997) include the Red Sea in the geographical distribution.

\section{Genus Tripneustes L. Agassiz, 1741}

Tripneustes gratilla (Linnaeus, 1758)

Material examined. KKiun/9908 (one specimen, juvenile); KKiun/9909 (one specimen, juvenile); KKiun/9912 (one specimen).

Taxonomic description. See Mortensen, 1943a: 500-508, figs 306, 307, pls 33 figures 1-3, pl. 34 figures 2-6, pl. 35 figures 3-4, pl. 37 figs 1-2, 4-10, pl. 38 figures 1-4, pl. 56 figure 11; Clark \& Rowe, 1971: p. 156; figure 65 b, p. 153; pl. 24 figure 8; pl. 31 figure 16.

Field description. Large-bodied sea urchin (test diameter 'up to $120 \mathrm{~mm}$ ) with high almost globular (up to $55 \mathrm{~mm}$ ) test, with numerous small whitish primary spines in the interambulacral areas, and with 10 darker bands corresponding to the podia (not the pedicellaria which are much smaller). Naked test: only one in three or four ambulacral plates with a primary tubercle; pore-pairs in horizontal arcs and spaced to form three distinct series.

Abundance in the Kiunga Marine Reserve. Abundant.

Local distribution. Reported by all the researchers that sampled in this region (see e.g. Bell, 1903 who reports it as Hipponoe variegata from Zanzibar or Lambert (1921-22) who reports it from Madagascar). A.M. Clark \& Rowe (1971) list it as a tropical Indo-Pacific species from East Africa (with the Red Sea) up to Hawaii (see also Mortensen, 1943a; Tortonese, 1955; A.M. Clark \& Courtman-Stock, 1976; Rowe \& Richmond, 1997).

Remarks. Although this species is not harvested in the Kiunga Marine Reserve, nor in Kenya (as far as we know), it is suitable for human consumption. The large population numbers and the synchronised lunar reproductive cycle (Muthiga, pers. comm.), whereby the gonads grow large enough for harvesting once a month, make it a species with a high 
economic potential. We observed harvesting of this species in northern Kwazulu Natal (Bangha Nek), Republic of South Africa.

Order Stiridonta Jackson, 1912

Family Stomopneustidae Pomel, 1883

Genus Stomopneustes L. Agassiz, 1841

Stomopneustes variolaris (Lamarck, 1816)

Material examined. KKiun/9910 (three specimens).

Taxonomic description. See Mortensen, 1935: 507-512, figure 301, 302, pl. 71 figures 35, pl. 72 figs 1, 2, pl. 89 figures 16-26; Clark \& Rowe, 1971: p. 153; figure 65a, p. 153; figure $66, \mathrm{p} .154 ; \mathrm{pl} .23$ figure 6 .

Field description. Medium sized species (horizontal test diameter up to $80 \mathrm{~mm}$ ); test round, with large (up to $80 \mathrm{~mm}$ long), solid, slightly tapering green-blue primary spines. Naked test: tubercles neither perforated nor crenulated; ambulacral plates doubly compound, at the ambitus one very large ambulacral tubercle corresponds to up to six arcs.

Abundance in the Kiunga Marine Reserve. Abundant. This species was present in large numbers in almost all the sampling sites, which is in agreement with the observations made by Obura et al. (1998) in the same marine reserve.

Local distribution. Humphreys (1981) reports it as 'extremely numerous' in several locations along the Kenyan coast. Also reported by Tortonese (1980) from Sar Uanle (southern Somalia), although he doesn't describe abundance. Other important records for the region include those by Ludwig (1899) from Zanzibar and by Lambert (1921-22) from Madagascar. A.M. Clark \& Rowe (1971) list it as a tropical Indo-Pacific species from East Africa (without the Red Sea) to the Islands of the South Pacific (see also Mortensen, 1935; A.M. Clark \& Courtman-Stock, 1976). Rowe \& Richmond (1997) also report its presence from the Red Sea. Haacke (1880) reported it from Mauritius.

\section{HOLOTHUROIDEA (Local Swahili Name: majongo ya baharini)}

We collected 57 specimens belonging to 23 different species of Holothuroidea. Samples of two more species were lost, due to inadequate preservation: Bohadschia subrubra and Stichopus herrmanni. According to literature, two more species-Holothuria (Mertensiothuria) pervicax and Holothuria (Selenkothuria) parva-are expected.

The holothurian fauna of the Kiunga Marine Reserve is now represented by 28 species. Actinopyga echinites, Holothuria (Cystipus) rigida, Holothuria (Platyperona) difficilis, Labidodemas pertinax, Stichopus chloronotus and Stichopus cf. monotuberculatus are new records for Kenya. Holothuria (Theelothuria) turriscelsa is a new record for the Indian Ocean.

Order Apodida Brandt, 1835

Family Synaptidae Burmeister, 1837

Subfamily Synaptinae Burmeister, 1837

Genus Synapta Escholtz, 1829 
Table 4. List of holothurians collected at the different localities in Kiunga Marine Reserve. The number of specimens refers to the number of animals that were encountered during a 60-minute sampling period. i.t. stands for intertidal. Depths apply to the low water level.

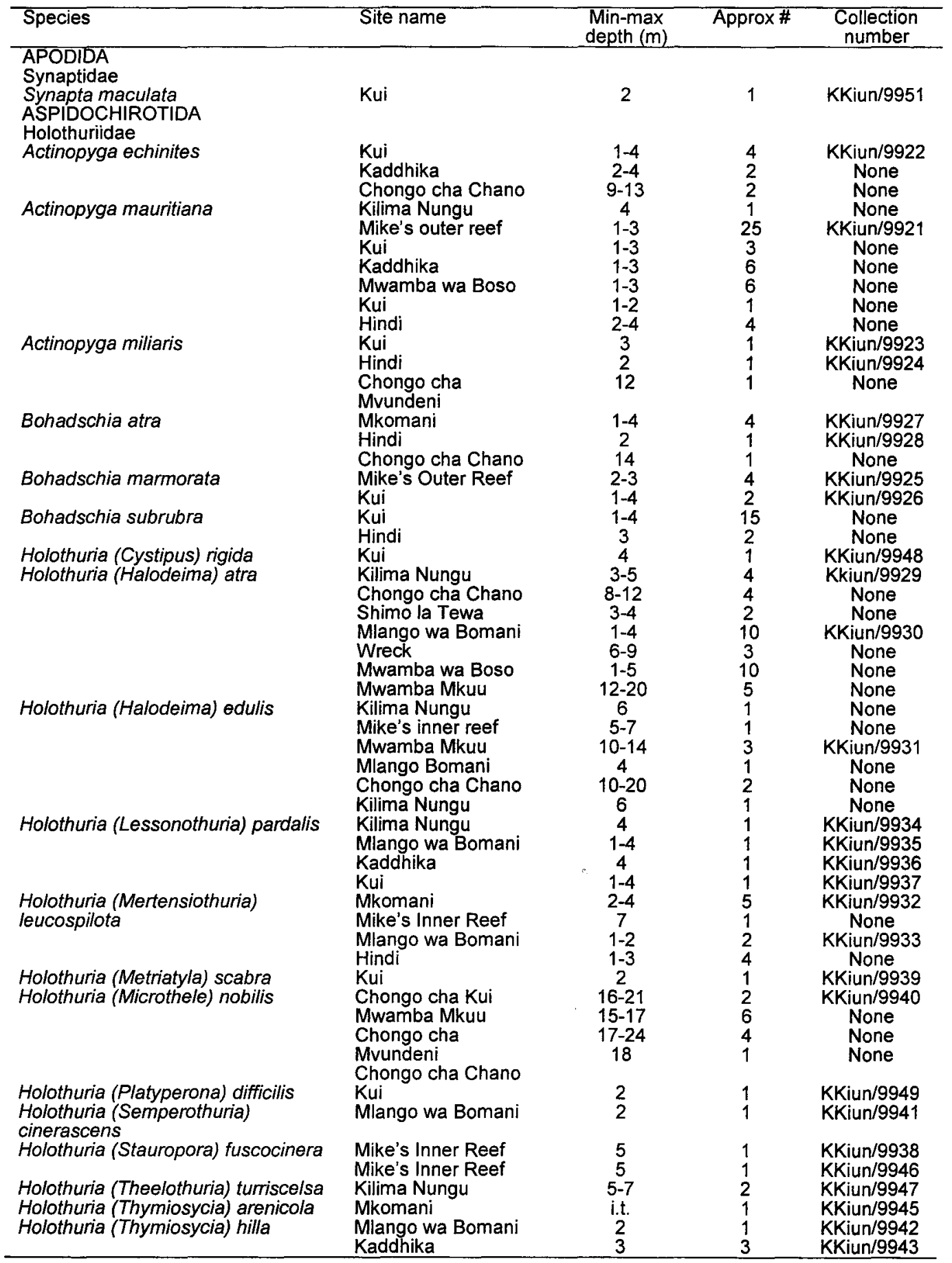




\begin{tabular}{|c|c|c|c|c|}
\hline Species & Site name & $\begin{array}{l}\text { Min-max } \\
\text { depth }(m)\end{array}$ & Approx \# & $\begin{array}{c}\text { Collection } \\
\text { number }\end{array}$ \\
\hline Holothuria (Thymiosycia) impatiens & Kui & 0.5 & 4 & KKiun/9944 \\
\hline Labidodemas pertinax & $\begin{array}{l}\text { Mkomani } \\
\text { Shimo la Tewa } \\
\text { Mlango wa Bomani } \\
\text { Kilima Nungu }\end{array}$ & $\begin{array}{c}4 \\
7 \\
1-4 \\
5\end{array}$ & $\begin{array}{l}1 \\
1 \\
2 \\
1\end{array}$ & $\begin{array}{l}\text { KKiun/9919 } \\
\text { None } \\
\text { KKiun/9920 } \\
\text { None }\end{array}$ \\
\hline $\begin{array}{l}\text { Stichopodidae } \\
\text { Stichopus hermanni }\end{array}$ & Kui & $1-4$ & 2 & None \\
\hline Stichopus cf. monotuberculatus & $\begin{array}{l}\text { Kilima Nungu } \\
\text { Mike's Inner Reef }\end{array}$ & $\begin{array}{l}5-7 \\
5-7\end{array}$ & $\begin{array}{l}2 \\
4\end{array}$ & $\begin{array}{c}\text { KKiun/9950 } \\
\text { None }\end{array}$ \\
\hline $\begin{array}{l}\text { Stichopus chloronotus } \\
\text { DENDROCHIROTIDA } \\
\text { Phyllophoridae }\end{array}$ & Hindi & 2 & 1 & None \\
\hline Afrocucumis africana & Kui & i.t. & 5 & KKiun/9918 \\
\hline
\end{tabular}

Synapta maculata (Chamisso \& Eysenhardt, 1821)

Material examined. KKiun/9951 (one specimen).

Taxonomic description. See Cherbonnier, 1988: 251-252; figure 112, p. 253.

Field description. Very large species with a distinct vermiform body, reaching lengths up to $3,000 \mathrm{~mm}$ and widths up to $35 \mathrm{~mm}$. Body colour dark green to brown with numerous transverse darker brown bands and radii with a longitudinal brown stripe. Mouth terminal surrounded by 15 feather-like tentacles. Anus terminal. Body wall smooth and thin, but very 'sticky' due to the numerous anchor spicules (visible with the naked eye when skin is held against the light) in the body tissue.

Abundance in the Kiunga Marine Reserve. Very rare. Only a single specimen was found in a small seagrass bed (location Kui). Not reported by Obura et al. (1998) from the Kiunga Marine Reserve.

Local distribution. Recorded in low numbers by Humphreys (1981) in Kenya (Mida Creek). Not found by Tortonese (1980) in Somalia. Other important local records include those by Lampert (1896) as Synapta beselii from Zanzibar; by Sloan et al. (1979) from Aldabra; and by Clark (1984) from the Seychelles. Massin (1999, figure 92: p. 109) shows an Indo-Pacific distribution from East Africa (with the Red Sea) to the Society Islands (Tahiti).

Order Aspidochirotida Grube, 1840

Family Holothuriidae Ludwig, 1894

Genus Actinopyga Bronn, 1860

Actinopyga echinites (Jaeger, 1833). P1. 1F

Material examined. KKiun/9922 (four specimens).

Taxonomic description. See Cherbonnier, 1988: 31, 32; figure 9, p.33.

Field description. Colour in life from light brown to chocolate brown, dorsally and ventrally, sometimes mottled with brown or black. Mouth ventral, with 20 brown peltate feeding tentacles. Anus terminal surrounded by five yellowish teeth. Trivium covered with numerous cylindrical podia, which are distributed distinctively in three ambulacral areas in smaller individuals, and scattered over the interambulacra in the largest individual. Bivium with fewer podia both in the radial and interradial areas.

Abundance in the Kiunga Marine Reserve. Common, although Obura et al. (1998) didn't report this very recognisable species in the Kiunga Marine Reserve.

Local distribution. Humphreys (1981) was unable to discern between $A$. echinites and $A$. miliaris he collected in Kenya (Mida Creek and Kibirijini Point). Levin (1979) reports this 
species (as A. plebeja) from Mombasa. Tortonese (1980) reports on two specimens from South Somalia (Sar Uanle, $20 \mathrm{~km}$ south of Kismayu). Other important records for eastern Africa/western Indian Ocean include those by Lampert (1896) and Panning (1944) from Zanzibar; by Hughes \& Gamble (1977) from Aldabra; by Lampert (1885), Ludwig (1899) and Clark (1984) from the Seychelles. Rowe \& Doty (1977) summarise the geographical distribution as "general distribution from scattered localities throughout the tropical IndoPacific, but not on Hawaii".

Remarks. This species is well known by local sea cucumber fishermen; they refer to it as 'iyongo wimbi' (like millet), which refers to the body colour and texture. In the Kiunga market it is sold for $1 \mathrm{KSh} /$ fresh specimen.

Obura et al. (1998) noted two species of Actinopyga in the Kiunga Marine Reserve: $A$. mauritiana and Actinopyga sp. While no collections were made by them, we can be quite sure that it is $A$. echinites since this species is easily distinguished from the other two Actinopyga species found in the Kiunga Marine Reserve: A. miliaris which is uniform black, and $A$. mauritiana (which they did identify). Humphreys (1981) collected an Actinopyga in the Channel to Mida Creek and on a wave-cut platform at Kibirijini Point in Kenya, however he was unable to identify it to the species level.

Actinopyga mauritiana (Quoy \& Gaimard, 1833)

Material examined. KKiun/9921 (one specimen).

Taxonomic description. See Cherbonnier, 1988: 16-18; figure 2 p. 19.

Field description. Species length up to $350 \mathrm{~mm}$, width up to $85 \mathrm{~mm}$. Colour very variable: dorsally chocolate brown with numerous conical papillae; ventrally white-grey to brown, densely covered with large cylindrical brown to green tube feet scattered over interambulacra and ambulacra. Bivium clearly distinguishable from trivium. Mouth ventral, surrounded by at least 25 short and stout, dark brown feeding tentacles which in turn are surrounded by a distinct collar of papillae. Anus terminal, guarded by five conspicuous teeth.

Abundance in the Kiunga Marine Reserve. Abundant, probably the most abundant species in the Reserve. Obura et al. (1998) found it in the Kiunga Marine Reserve.

Local distribution. Humphreys (1981) reports on specimens from Kenya (Big Tree Cave at the mouth of Mida Creek), and Tortonese (1980) from Somalia (Gesira, $18 \mathrm{~km}$ South of Kismayu). Other important records for eastern Africa/western Indian Ocean include those by Lampert (1896) from Zanzibar (as Muelleria mauritiana); by Lampert (1885) (as Muelleria mauritiana), Ludwig (1899) (as Muelleria mauritiana) and A.M. Clark (1984) from the Seychelles; by Quoy \& Gaimard (1833) (as Holothuria mauritiana, in Mitsukuri, 1912); by Ludwig (1883) (as Muelleria mauritiana) from Mauritius and by Sloan et al. (1979) from Aldabra.

Remarks. This species is also well known by local sea cucumber fishermen; they refer to it as 'iyongo bura'. In the Kiunga market it is sold for $5 \mathrm{KSh} /$ fresh specimen.

Actinopyga miliaris (Quoy \& Gaimard, 1833)

Material examined. KKiun/9923 (one specimen); KKiun/9924 (one specimen).

Taxonomic description - See Massin, 1996a: 12-13; figure 6, p. 13; Massin, 1999: 10-12; figures 5, p. 10 .

Field description. Species length up to $400 \mathrm{~mm}$, width up to $100 \mathrm{~mm}$. Colour in life uniform dark brown dorsally and ventrally (although some specimens may show a slightly lighter colour ventrally). Mouth ventral surrounded by 16 firm brown tentacles. Anus terminal surrounded by five easily noticeable yellow-orange teeth. Five to eight rows of podia with 
the same colouration as the body wall on the ventro-lateral radii, $12-15$ rows of podia on the ventro-median radius.

Abundance in the Kiunga Marine Reserve. Rare, only spotted in three locations (Kui, Kaddhika and Chongo Cha Chano). Not found by Obura et al. (1998) in the Kiunga Marine Reserve.

Local distribution. Humphreys (1981) found it only in one location on the Kenyan Coast (Mida Creek); Levin (1979) reports it from Mombasa; Tortonese $(1949,1951,1980)$ didn't report it from Somalia; but Price (1982) found it in the Red Sea, the Gulf of Aqaba and in the Gulf of Suez. Other important records from eastern Africa/western Indian Ocean include those by Lampert (1885) from Zanzibar (as Muelleria miliaris); by Haacke (1880) and Ludwig (1883) from Mauritius (as Muelleria miliaris). Massin's (1999, figure 6: p. 11) distribution map shows an Indo-Pacific distribution from East Africa (with the Red Sea) to the Fiji Islands. The Kiunga Marine Reserve is now the most northern point along the East African coast.

Remarks. This species is known by local sea cucumber fishermen although they fail to make a distinction with the other black species like Holothuria atra, $H$. leucospilota and Bohadschia atra; they refer to it as 'iyongo leusi' (black sea cucumber). In the Kiunga markets fishermen get $1 \mathrm{KSh}$ for a fresh specimen.

\section{Genus Bohadschia Jaeger, 1833}

Bohadschia atra Massin, Rasolofonirina, Conand \& Samyn, 1999

Material examined. KKiun/9927 (three specimens); KKiun/9928 (one specimen).

Taxonomic description. See Massin et al., 1999: 151-160; figure 1, p. 152; figure 2, p. 154; pl.1.B, D, p. 159.

Field description. Species up to $400 \mathrm{~mm}$ long and $150 \mathrm{~mm}$ wide. Deep brown to black bivium with numerous lighter brown to red spots. Trivium slightly lighter in colour, without red spots. Ventral podia scattered over radial and interradial areas, dorsal podia also scattered but less numerous. Mouth ventral, surrounded by 18-20 black tentacles, anus dorsal. Cuvierian tubules present and very readily ejected in large quantities.

Abundance in the Kiunga Marine Reserve. Common. Minor range extension from Shariani (some $30 \mathrm{~km}$ north of Mombasa). Not reported by Obura et al. (1998) from the Kiunga Marine Reserve.

Local distribution. Bohadschia atra Massin et al., 1999 was recently described by one of us (YS in Massin et al., 1999). That paper also discusses the distribution. The Kiunga Marine Reserve is now documented here as the most northern point of its range.

Bohadschia subrubra (Quoy \& Gaimard, 1833) P1.1G

Material examined. None, picture $\mathrm{G}$ on pl. 1 leaves no doubt over the identification.

Taxonomic description - See Massin et al., 1999: 151-160; figure 3, p. 155; figure 4, p. 156; figure 5, p. 157; pl.1A, C, D, p. 159.

Field description. Species up to $350 \mathrm{~mm}$ long and $130 \mathrm{~mm}$ wide. Bivium brown to orange with unevenly distributed dark brown areas. Trivium white, with tiny black spots. Numerous ventral podia, white, very long, and scattered over the whole surface. Dorsal podia less numerous, scattered, white, clearly visible against the orange background. Mouth ventral surrounded by 18 stout, white feeding tentacles. Anus dorsal, unguarded by anal teeth or papillae. Cuvierian tubules present and very readily ejected in large quantities. 
Abundance in the Kiunga Marine Reserve. Common. Also reported by Obura et al. (1998) from the Kiunga Marine Reserve.

Local distribution. Minor range extension from Shariani (some $30 \mathrm{~km}$ north of Mombasa). Bohadschia subrubra was recently redescribed (Massin et al., 1999). That paper also discusses the distribution.

Remarks. Species well-known by the local fishermen, who refer to it as 'iyongo la tambi' (meaning spaghetti; referring to the readily ejected Cuvierian tubules); the other Bohadschia sp. get the same common name. It has a limited commercial value.

The specimens identified by Humphreys (1981) as Bohadschia koellikeri, were not seen by us. However, the description (p. 33) of the colour in life ("bold camouflage pattern in deep brown and beige, tube feet spread over surface give white dotted surface and often hold marine angiosperm leaves over the surface of the animal") is characteristic of Bohadschia subrubra. This species is quite common in the studied site, which is now considered to be the northern edge of its range.

\section{Bohadschia marmorata Jaeger, 1833}

Material examined. KKiun/9925 (three specimens); KKiun/9926 (two specimens).

Taxonomic description. See Cherbonnier, 1988: 36-38; fig 11, p. 37.

Field description. Large species up to $300 \mathrm{~mm}$ long and $100 \mathrm{~mm}$ wide. Body colour yellowwhite ventrally and laterally, brownish dorsally, spotted by numerous small brown spots corresponding to conical podia. Dorsally, transversal banding is sometimes visible. Mouth ventral, surrounded by 15-20 light brown, relatively small tentacles which in turn are surrounded by a circle of brown podia; relatively large terminal anus surrounded by a brown line. Ventral tube feet spread in the ambulacral and the interambulacral zones. Bivium covered by conical tube feet surrounded at their base by a small brownish circle. Cuvierian tubules present.

Abundance in the Kiunga Marine Reserve Common. First record for the Kiunga Marine Reserve.

Local distribution. Humphreys (1981) reports it from Kenya in the Mida Channel and throughout the Watamu Marine Park; Levin (1979) from Mombasa. Sloan et al. (1979) reports on the species from Aldabra; Clark (1984) from the Seychelles. Another important record for eastern Africa/western Indian Ocean is Haacke (1880) from Mauritius (as Holothuria utrimquestigmosa). It is reported throughout the shallow waters of the tropical zone of the Indo-Pacific.

Remarks. Obura et al. (1998) only observed one species of Bohadschia, which they identified as Bohadschia vitiensis. This species is listed and depicted in Richmond's book on the fauna and flora of eastern Africa (1997). However without microscopic examination of the spicules no differentiation with Bohadschia marmorata can be made (See also Massin, 1996a for a discussion). Therefore we would include $B$. marmorata in the fauna of Kiunga Marine Reserve, and (for now) not $B$. vitiensis.

Genus Holothuria Linnaeus, 1767

Subgenus Cystipus Haacke, 1880

Holothuria (Cystipus) rigida (Selenka, 1867) Pl. 1H

Material examined. KKiun/9948 (one specimen).

Taxonomic description. See Cherbonnier, 1988: 126-127 \& 129; figure 51, p. 127. 
Field description. Medium-sized species (125 mm long and $25 \mathrm{~mm}$ wide). Body colour white to yellow ventrally and somewhat lighter dorsally. Podia in trivium evenly distributed over the radial and interradial areas; conical podia in bivium distributed in three interradial areas. Anus terminal, surrounded by conical papillae, mouth ventral, with 20 small, yellowbrown tentacles.

Abundance in the Kiunga Marine Reserve. Very rare, only observed once. Not observed by Obura et al. (1998) in the Kiunga Marine Reserve.

Local distribution. First record for Kenya. Other important records from eastern Africa/western Indian Ocean include those by Selenka (1867) from Zanzibar (as Stichopus rigidus), by Haacke (1880) (as Cystipus pleuripus) and by Ludwig (1883) (as Holothuria pleuripus) from Mauritius, by Sloan et al. (1979) from Aldabra, by Clark (1984) from the Seychelles; by Cherbonnier (1988) from Iles Glorieuses.

Remarks. Selenka's (1867: p. 317) description (as Stichopus rigidus) says that $H$. (Cystipus) rigida contains few long tubules of Cuvier. In the single specimen we collected these are not visible.

\section{Subgenus Halodeima Pearson, 1914}

Holothuria (Halodeima) atra Jaeger, 1833

Material examined. KKiun/9929 (one specimen); KKiun/9930 (five specimens).

Taxonomic description. See Cherbonnier, 1988: 73-74; figure 28, p. 74.

Field description. Uniform black species with a cylindrical body, reaching sizes up to 300 $\mathrm{mm}$ long and $70 \mathrm{~mm}$ wide. Ventrally short, black, cylindrical podia scattered over the radial and interradial areas; dorsally short, black, conical tube feet over the total surface. Mouth ventral, surrounded by 20 short, black feeding tentacles. Anus terminal, unguarded. Cuvierian tubules always absent. Body wall often covered with fine sand.

Abundance in the Kiunga Marine Reserve. Abundant. Also reported in the Kiunga Marine Reserve by Obura et al. (1998).

Local distribution. Humphreys (1981) reports $H$. atra from the Watamu Marine Park, and Tortonese (1980) from Somalia (Sar Uanle, $20 \mathrm{~km}$ South of Kismayu). Massin's distribution map (1999; figure 13: p. 21) shows an Indo-Pacific distribution from the coast of East Africa (with the Red Sea) to the coast of western America.

Remarks - In the field, this species is easily confused with $H$. leucospilota, the other abundant black species. Table 5 lists some characters recognisable in the field.

Holothuria (Halodeima) edulis Lesson, 1830

Material examined. KKiun/9931 (one specimen).

Taxonomic description. See Cherbonnier, 1988: 75-77; figure 29, p. 76.

Field description. Species can be up to $300 \mathrm{~m}$ long and $50 \mathrm{~mm}$ wide. Body colour in life: large chocolate brown to dark-grey patches dorsally, salmon pink to red ventrally. Body elongated and slender; somewhat wrinkled. Mouth ventral surrounded by 20 yellow to light-pink tentacles. Anus terminal, unguarded by teeth or papillae, but bordered by a dark-pink circle. Trivium covered by short tube feet, scattered over both ambulacra and interambulacral areas. Bivium with few tube feet in total area. Cuvierian tubules absent.

Abundance in the Kiunga Marine Reserve. Rare, although also reported in Obura et al. (1998) in the Kiunga Marine Reserve. 
Table 5. Field characters to discem Holothuria (Mertensiothuria) leucospilota from Holothuria (Halodeima) atra.

\begin{tabular}{|c|c|c|}
\hline Character & H. atra & H. leucospilota \\
\hline Colour & Uniform black & $\begin{array}{l}\text { Dark brown-red to black, } \\
\text { ventral side sometimes } \\
\text { lighter }\end{array}$ \\
\hline $\begin{array}{l}\text { Size } \\
\text { Podia on bivium }\end{array}$ & $\begin{array}{l}\text { Up to } 300 \mathrm{~mm} \text { long } \\
\text { Few, conical, radial and interradial } \\
\text { areas }\end{array}$ & $\begin{array}{l}\text { Often longer than } 300 \mathrm{~mm} \\
\text { Few, conical, in } 2 \text { to } 3 \text { rows } \\
\text { in the radial areas }\end{array}$ \\
\hline Distribution of podia on trivium & $\begin{array}{l}\text { Few, cylindrical, black, very short, in } \\
\text { radial and interradial areas }\end{array}$ & $\begin{array}{l}\text { Numerous, cylindrical, } \\
\text { short but thick with brown } \\
\text { sucking disc, in } 4 \text { to } 5 \text { rows } \\
\text { in radial areas }\end{array}$ \\
\hline Morphology of tentacles & 20, short, black & $\begin{array}{l}20 \text {, long, dark brown to } \\
\text { black }\end{array}$ \\
\hline Habitat & $\begin{array}{l}\text { Exposed on sand flats and in sea grass } \\
\text { beds }\end{array}$ & $\begin{array}{l}\text { Often partially concealed } \\
\text { below coral block }\end{array}$ \\
\hline Body covering & $\begin{array}{l}\text { Often covered with fine sand, with bare } \\
\text { patches }\end{array}$ & Not covered with sand \\
\hline $\begin{array}{l}\text { Tubules of Cuvier } \\
\text { Red fluid }\end{array}$ & $\begin{array}{l}\text { Always absent } \\
\text { Release of red fluid after rubbing }\end{array}$ & $\begin{array}{l}\text { Always present } \\
\text { No release of toxic red } \\
\text { fluid after rubbing }\end{array}$ \\
\hline
\end{tabular}

Local distribution. Not observed along the Somalian coast by Tortonese (1949; 1951; 1980), nor by Humphreys (1981) along the Kenyan coastline. Other important records for eastern Africa include those by Ludwig (1875) from Zanzibar, by Cherbonnier (1988) from northern Madagascar (Nosy Bé). Massin (1999; figure 14: p. 22) shows an Indo-Pacific distribution from East Africa (with the Red Sea) to Tahiti.

Remarks - Although the name $H$. edulis suggests that this species is edible, in Kenya no real market exists for this low-valued species. The Kiunga fishermen do not have a common name for it.

\section{Subgenus Lessonothuria Deichmann, 1958}

Holothuria (Lessonothuria) pardalis Selenka, 1867

Material examined. KKiun/9934 (one specimen); KKiun/9935 (one specimen); KKiun/9936 (one specimen); KKiun/9937 (one specimen).

Taxonomic description. Cherbonnier, 1988: 117-119; figure 47, p. 118; Massin, 1999: 2527 ; figure 18 , p. 26.

Field description. Relatively small species, up to $100 \mathrm{~mm}$ long and $40 \mathrm{~mm}$ wide. Total body wall white-yellow, with two rows of conspicuous dark areas on the dorsal side and with innumerable small yellow areas giving the animal a speckled appearance. Rough bivium clearly separated from the smoother trivium. Bivium with small homogeneously spread papillae, more numerous at the posterior side; trivium with long cylindrical podia in the radial areas (two to four rows laterally; four to five rows in the median area), however with some spreading into the interambulacral areas. Mouth ventral, surrounded by 17 long 'dendritic' tentacles, surrounded at their base by long conical papillae. Anus terminal, surrounded by conical papillae. Cuvierian tubules absent

Abundance in the Kiunga Marine Reserve. Rare, possibly common. Not reported by Obura et al. (1998) from the Kiunga Marine Reserve.

Local distribution. Humphreys (1981) reports it as abundant in the channel to Mida Creek, on the rock reefs near Big Tree Caves and in the Watamu Marine Park. Tortonese (1980) reports it abundant at Bender Mtoni (20 km South of Kismayu), Somalia. Other important 
records for eastern Africa include those by Selenka (1867) from Zanzibar (as Holothuria subditiva); by Haacke (1880) from Mauritius (as Labidodemas punctulatum); by Sloan et al. (1979) from Aldabra; by Clark (1984) from the Seychelles. Massin (1999, figure 19: p. 27) shows an Indo-Pacific distribution from East Africa (with the Red Sea) to the West coasts of central and North America.

Remarks - Since this species lives unexposed, hiding under coral blocks on coral debris and crustose algae, its abundance is possibly much larger then suggested here.

Subgenus Mertensiothuria Deichmann, 1958

Holothuria (Mertensiothuria) leucospilota (Brandt, 1835)

Material examined. KKiun/9932 (one specimen); KKiun/9933 (one specimen).

Taxonomic description. See Cherbonnier, 1988: 112-114; figure 45, p. 113; Massin, 1999: 27-30; figure 20, p. 29.

Field description. Relatively large cylindrical and elongate species, reaching lengths of over $300 \mathrm{~mm}$. Its body wall is coloured in life uniform brown to reddish black, sometimes somewhat lighter ventrally. Ventral tube feet large, but relatively short, with brown to grey sucking disc, distributed in the radial areas with major scattering into the interradial areas. Soft, brown papillae in the radial areas of the dorsal side. Mouth ventral with 20 large, black tentacles. Anus terminal. Cuvierian tubules present.

Abundance in the Kiunga Marine Reserve. Abundant, although not reported by Obura $e t$ al. (1998) from the Kiunga Marine Reserve.

Local distribution. Humphreys (1981) reports it from Mida Creek and the Watamu Marine Park; Tortonese (1980) reports it from Bender Mtoni, $20 \mathrm{~km}$ South of Kismayu. Other important records for eastern Africa include those by Selenka (1867) from Zanzibar as $H$. vagabunda; by Sloan et al. (1979) from Aldabra; by A.M. Clark (1984) from the Seychelles. Massin (1999, figure 21: p. 29) shows an Indo-Pacific distribution from East Africa (with the Red Sea) to the West coasts of tropical America.

\section{Subgenus Metriatyla Rowe, 1969}

Holothuria (Metriatyla) scabra Jaeger, 1833

Material examined. KKiun/9939 (1 specimen).

Taxonomic description. See Cherbonnier, 1988: 135-137; figure 55, p. 136; Massin, 1999: 30-33; figure 22, p. 31.

Field description. Species can be up to $400 \mathrm{~mm}$ long and $150 \mathrm{~mm}$ wide. Body colour dorsally grey with transverse narrow white bands; ventral side light grey with numerous homogeneously distributed grey spots corresponding to the tube feet. Grey tube feet in trivium and bivium, spread over the ambulacral and interambulacral areas, in bivium less numerous. Papillae always dorsal, small, and black, surrounded by a narrow grey ring, sparsely distributed over all the bivium. Mouth ventral, surrounded by 20 grey tentacles; anus terminal. Cuvierian tubules absent.

Abundance in the Kiunga Marine Reserve. Very rare, also observed in the Kiunga Marine Reserve by Obura and his team (1998).

Local distribution. Humphreys (1981) reports it from Kenya (Malindi Marine Park, Mida Creek, Suda Island); Panning (1941) from Mombasa, and Somalia. Other important records for eastern Africa/western Indian Ocean include those by Selenka (1867) from Zanzibar as Holothuria tigris; by Haacke (1880, in Théel, 1886), Ludwig (1883) and Théel (1886) from 
Mauritius; and by Clark (1984) from the Seychelles. Massin (1999, figure 23: p. 32) shows an Indo-Pacific distribution from East Africa (with the Red Sea) to the Cook Islands.

Remarks. This species probably was abundant up to a few years ago, but extensive fishing caused a sharp decline in the abundance. An old synonym of Holothuria scabra Jaeger, 1833 is Holothuria tigris Selenka, 1867, the local fishermen refer to that old name in their language: they call this species 'iyongo tigri'. It has a high market value, of $20 \mathrm{KSh} / \mathrm{fresh}$ specimen.

\section{Subgenus Microthele Brandt, 1835}

Holothuria (Microthele) nobilis (Selenka, 1867)

Material examined. KKiun/9940 (two specimens).

Taxonomic description. See Cherbonnier, 1988: 142-144; figure 58, p. 143; Massin, 1999: $33-38$; figure 24 , p. 34; figure 25 , p. 36 ; figure 26 , p. 37.

Field description. Loaf-shaped body, with the dorsal side round and coloured grey to black, and ventral side flattened and uniform white to grey. Lateral four to eight large white-yellow 'teats' (i.e. conical projections) separate the trivium from the bivium. Grey tube feet with brown sucking disk scattered all over the ventral surface, black tube feet with brown sucking disk on dorsal side. Mouth ventral with 20 grey to dark brown, large feeding tentacles with brown spots on the stalk. Anus dorsal surrounded by five small white teeth. Body wall approximately $10 \mathrm{~mm}$ thick, often covered with sand. Cuvierian tubules present in both specimens.

Abundance in the Kiunga Marine Reserve. Common. Also reported from the Kiunga Marine Reserve by Obura et al. (1998).

Local distribution . Humphreys (1981) reports it from Kenya in the Watamu Marine Park and in Mida Channel. Other important records for eastern Africa include those by Panning (1941) from Somalia (unspecified locality); by Selenka (1867) and Semper (1869) from Zanzibar as Muelleria nobilis; by Sloan et al. (1979) from Aldabra; by Clark (1984) from the Seychelles. Massin (1999, figure 27: p. 38) shows an Indo-Pacific distribution from East Africa (with the Red Sea) to Easter Islands.

\section{Subgenus Platyperona Rowe, 1969}

Holothuria (Platyperona) difficilis Semper, 1868

Material examined. KKiun/9949 (one specimen).

Taxonomic description. See Cherbonnier, 1988: 99-101; figure 40, p. 102; Massin, 1999: 38-40; figure 28, p. 39.

Field description. Cylindrical body up to $120 \mathrm{~mm}$ in length (see Rowe, 1969), bivium variegated purple-brown, trivium slightly lighter and more uniform in colouration. Dorsal pedicels dark brown, surrounded at their base by a brown ring-like area, scarce in number, distributed over the total area, ventral tube feet more numerous, distributed mainly in the radial areas (especially posteriorly) in four to six rows, although some spreading into the interradial areas can occur. Anus terminal guarded by five small, brown, pointed teeth and numerous non-calcified papillae. Mouth ventral surrounded by 20 small but firm tentacles, green-brown in colouration. Body wall rough, relatively thin (2-3 mm). Large Cuvierian tubules present, however not readily ejected.

Abundance in the Kiunga Marine Reserve. Very rare. Not reported by Obura et al. (1998) from the Kiunga Marine Reserve. 
Local distribution. First record for Kenya. Previously important records for eastern Africa/western Indian Ocean were made by Haacke (1880) as Muelleria pervula and Ludwig (1883) as Holothuria difficilis in Mauritius; by Sloan et al. (1979) from Aldabra; by Clark (1984) from the Seychelles; by Cherbonnier (1988) from Madagascar. Massin (1999, figure 29: p. 40) shows an Indo-Pacific distribution from East Africa (with the Red Sea) to the West coasts of America.

\section{Subgenus Semperothuria Deichmann, 1958}

Holothuria (Semperothuria) cinerascens (Brandt, 1835)

Material examined. KKiun/9941 (one specimen).

Taxonomic description. See Cherbonnier, 1988: 70-72; figure 27, p. 72.

Field description. Medium sized species up to $120 \mathrm{~mm}$ in length and $40 \mathrm{~mm}$ in width. Redbrown to purple body colour, somewhat lighter ventrally. Yellow-brown tube feet scattered over the total ventral and dorsal surface. The dorsal tube feet are less numerous, short, and surrounded at their base by a yellow circle. Twenty large and branched red-purple tentacles around the ventral mouth. Anus dorsal, unguarded. Body wall soft and rather smooth. Cuvierian tubules always absent.

Abundance in the Kiunga Marine Reserve. Very rare. Not reported by Obura et al. (1998) from the Kiunga Marine Reserve.

Local distribution. Reported from Kenya-Mida channel and Kibirijini point-by Humphreys (1981), and from Mombasa by Levin (1979). From southern Somalia-Bender Mtoni, $20 \mathrm{~km}$ South of Kismayu-by Tortonese (1980). Other important records for eastern Africa/western Indian Ocean include those by Lampert (1896) from Zanzibar; by Ludwig (1883) from Mauritius as Holothuria pulchella; by Sloan et al. (1979) from Aldabra; by Lampert (1885), Ludwig (1899) and by Clark (1984) from the Seychelles.

Remarks. It is possible that this species is more abundant than reported here, since its hiding behaviour under coral rocks makes it hard to find.

\section{Subgenus Stauropora Rowe, 1969}

Holothuria (Stauropora) fuscocinerea Jaeger, 1833

Material examined. KKiun/9938 (one specimen).

Taxonomic description. See Massin, 1999: 48-51; figure 38, p. 50.

Field description. Specimens can be up to $200 \mathrm{~mm}$ long and $50 \mathrm{~mm}$ wide. Bivium mottled green-grey with dark spots (white-tipped conical papillae distributed over the total surface; trivium grey-green with homogeneously distributed brown spots corresponding to cylindrical tube feet (with white sucking disc). Mouth ventral surrounded by 20 yellow-green stout tentacles, in turn surrounded by a collar of small yellow conical papillae. Anus dorsal surrounded by a dark purple ring. Cuvierian present, very thick, white and very readily ejected.

Abundance in the Kiunga Marine Reserve. Very rare. Only seen once during a night dive. Obura et al. (1998) failed to find it in the Kiunga Marine Reserve.

Local distribution. Humphreys (1981) recorded a single specimen in the Watamu Marine Park; Tortonese (1980) failed to find it in Somalia. Pearson (1913) reports it as a "not very common species with an Indo-Pacific distribution". Massin (1999, figure 39: p. 51) shows an Indo-Pacific distribution from East Africa (with the Red Sea) to the Gulf of California; quite a few records are now known. 


\section{Subgenus Theelothuria Deichmann, 1958}

Holothuria (Theelothuria) turriscelsa Cherbonnier, 1980 Pl. 2A, B

Material examined. KKiun/9947 (two specimens).

Taxonomic description. See Cherbonnier, 1980: 644; figure $15 \mathrm{~A}-\mathrm{L}$, pl. 1E.

Field description. Relatively large species reaching lengths of about $250 \mathrm{~mm}$ and widths of about $75 \mathrm{~mm}$. Well-developed white to almost translucent Cuvierian tubules, which is very readily ejected (further disturbance results in the ejection of the situs viscerum). Colour yellow-green ventrally with numerous dark green spots corresponding to cylindrical brown tube feet with distinct white sucking discs; mottled dark green to yellow dorsally; the green patches correspond to the basis of the short, well-developed dark brown conical papillae; the smaller yellow spots bear shorter dark brown papillae. Bivium clearly separated from the flattened trivium. Mouth ventral surrounded by 19-20 large, yellow-green tentacles. Anus dorso-terminal, guarded by dark-brown conical papillae. Tube feet spread evenly over the ambulacra and interambulacra in the trivium; papillae in the bivium spread over the total surface. Body wall several mm thick.

Abundance in the Kiunga Marine Reserve. Rare. Not reported by Obura et al. (1998) in the Kiunga Marine Reserve.

Local distribution. This recently described species is reported here as a new species for the Indian Ocean. Up till now it was only known from four localities: Indonesia (Sulawesi) (Massin, 1999), Mariana Islands (Guam) (Kerr et al., 1992), New Caledonia (Cherbonnier, 1980; Cherbonnier \& Féral, 1984; Féral \& Cherbonnier, 1986); and the Society Islands (Tahiti) (Cherbonnier \& Féral, 1984) (see also distribution map Massin, 1999, figure 43: p. 55). One of us recorded it earlier in Kenya and Tanzania, Pemba Island (Samyn, pers. observation).

Remarks. This species was observed during a night dive in a single location. Due to its nocturnal habits, it is possible that this species is more common than reported here.

\section{Subgenus Thymiosycia Pearson, 1914}

Holothuria (Thymiosycia) arenicola Semper, 1868

Material examined. KKiun/9945 (one specimen).

Taxonomic description. See Cherbonnier, 1988: 82-84; figure 32, p. 83; Massin, 1996a: 27-30; figure 19, p. 29.

Field description. Small burrowing species, up to $150 \mathrm{~mm}$ long and $25 \mathrm{~mm}$ wide. Body cylindrical, tapering at both ends. Colour grey to yellow with numerous tiny black spots ventrally; dorsally yellowish-grey with two rows of conspicuous brown areas lying in narrow and shallow longitudinal scars, and with numerous tiny black spots. Mouth terminal surrounded by 18 feeding tentacles. Large terminal anus guarded by five groups of four to five papillae. White cylindrical tube feet in trivium distributed in the radial areas, but with major spreading into the interradial area; in bivium spread evenly in the total area. Cuvierian tubules absent.

Abundance in the Kiunga Marine Reserve. Very rare. Not observed by Obura et al. (1998) from the Kiunga Marine Reserve.

Local distribution - First record for Kenya. Humphreys (1981) failed to find it in Kenya. It was however recorded from Somalia (Sar Uanle, $20 \mathrm{~km}$ South of Kismayu) by Tortonese (1980). Other important records for eastern Africa/western Indian Ocean include those by Sloan et al. (1979) from Aldabra; by Haacke (1880) from Mauritius; by Ludwig (1899) as 
Holothuria maculata and by Clark (1984) from the Seychelles; by Lampert $(1885 ; 1896)$ and Ludwig (1899) as Holothuria maculata from Zanzibar; by Haacke (1880) and Ludwig (1883) as Holothuria maculata from Mauritius. Rowe \& Doty (1977) and Massin (1996b) report on the distribution of $H$. arenicola as being tropical Indo-West Pacific (with the Red Sea).

Remarks. The burrowing behaviour of this species makes it very difficult to find: only an inand outflow in the sand is visible, so abundance is possibly much larger than reported here.

Holothuria (Thymiosycia) hilla Lesson, 1830

Material examined. KKiun/9942 (one specimen); KKiun/9943 (three specimens).

Taxonomic description. See Cherbonnier, 1988: 85-87; figure 34, p. 88; Massin, 1999: 55-57.

Field description. Cylindrical body up to $150 \mathrm{~mm}$ long and $35 \mathrm{~mm}$ wide. Bivium chocolate brown with longitudinal rows of yellow pointed papillae; trivium slightly lighter with long cylindrical yellow tube feet arranged in two to three rows in the lateral radial areas and in three to four rows in the median ambulacrum. Mouth ventral surrounded by 19 to 20 yellow tentacles. Anus terminal surrounded by small conical papillae. Body wall thin. Cuvierian tubules present but not readily ejected.

Abundance in the Kiunga Marine Reserve. Common, although not found by Obura et al. (1998) in the Kiunga Marine Reserve.

Local distribution. Previously reported from Kenya by Humphreys (1981) from Big Tree Caves in front of Mida Creek; from southern Somalia (Bender Mtoni) by Tortonese (1980). Other important records for eastern Africa include those by Selenka (1867) as Stichopus gyrifer and Ludwig (1899) as Holothuria monacaria from Zanzibar; by Haacke (1880) as Labidodemas neglectum and Ludwig (1883) as Holothuria monacaria from Mauritius; by Sloan et al. (1979) from Aldabra; by Ludwig (1899) as Holothuria monacaria and by Clark (1984) from the Seychelles. Massin (1999, figure 44: p. 56) shows an Indo-Pacific distribution from East Africa (with the Red Sea) to the Society Islands.

Holothuria (Thymiosycia) impatiens (Forsskål, 1775)

Material examined - KKiun/9944 (four specimens).

Taxonomic description. See Cherbonnier, 1988: 89-91; figure 35, p. 90.

Field description. Species reaching sizes up to approximately $120 \mathrm{~mm}$ in length and $30 \mathrm{~mm}$ in width. Trivium light brown with some lighter areas corresponding to the basis of the tube feet; bivium somewhat darker with dark brown areas more or less connected to form transverse bands. Mouth terminal, surrounded by 18 relatively small tentacles; anus terminal

Plate 2. A, B. Holothuria (Theelothuria) turriscelsa Cherbonnier, 1980; C. Stichopus chloronotus Brandt, 1835; D. Labidodemas pertinax Ludwig, 1875; E. Stichopus herrmanni Semper, 1868; F. Stichopus cf. monotuberculatus (Quoy \& Gaimard, 1833), ventral view; G. Stichopus cf. monotuberculatus (Quoy \& Gaimard, 1833), dorsal view; $H$. Stichopus cf. monotuberculatus (Quoy \& Gaimard, 1833): A. tables from the ventral body wall; $B$. C-shaped rods from the ventral body wall; $C$. tables and rosettes from the dorsal body wall; $D$. modified rods from the ventral body wall; $E$. plates, tables and $X$-shaped rods from the ventral tube feet; $F$. rods and tables from the dorsal papillae; $G$. rods from the tentacles; $H$. detail of the distal end of a rod from the tentacle. Scale bars are $100 \mu m$. All pictures by $Y$. Samyn. 

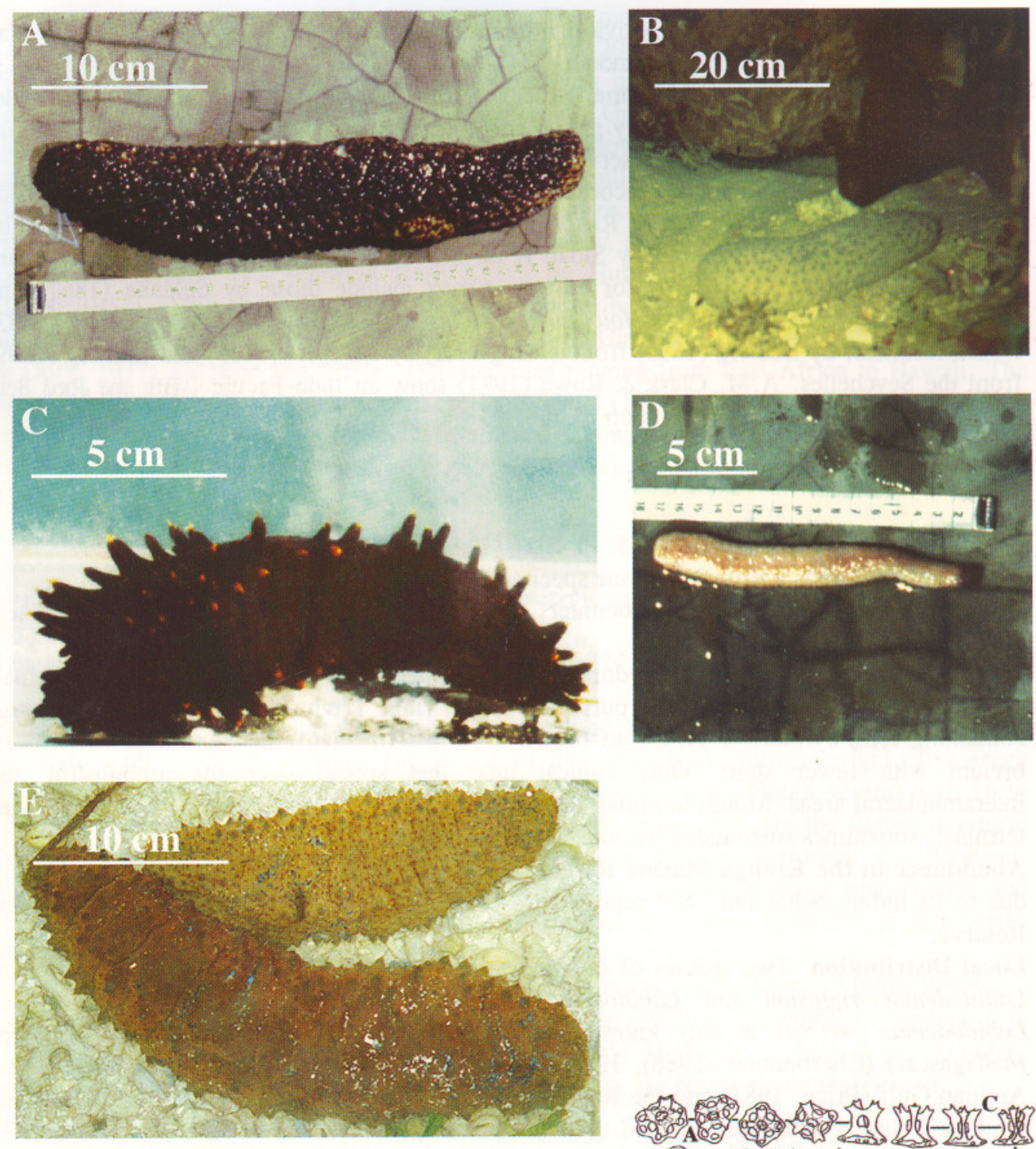

कogs

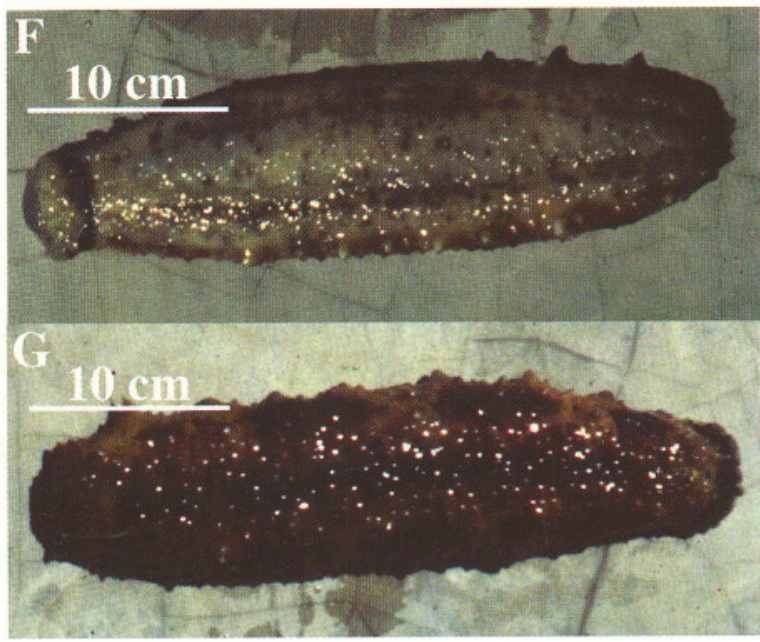
C C m

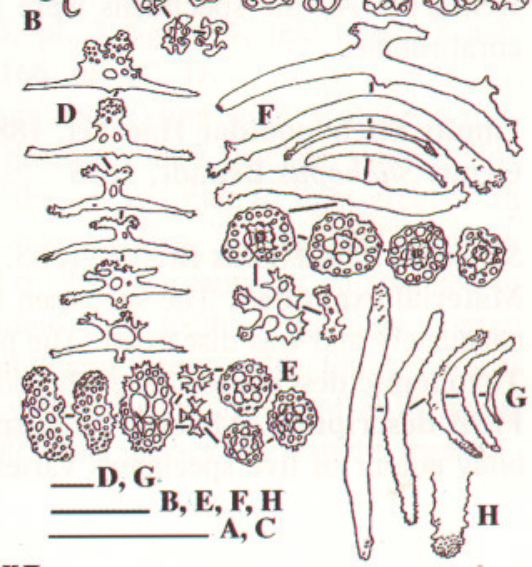

H 
with five conical papillae. Thick Cuvierian tubules present but not readily ejected. Body wall only few mm thick and relatively smooth.

Abundance in the Kiunga Marine Reserve. Rare, found only in one location under boulders and coral heads over sandy gravel and coarse rubble. Not observed by Obura et al. (1998) from the Kiunga Marine Reserve.

Local distribution. Previously recorded from Kenya by Humphreys (1981) from Mida creek, Watamu Marine Park and Ras Ngomeni; from Sar Uanle (southern Somalia) by Tortonese (1980); from Aldabra by Sloan et al. (1979); and from the Seychelles by Clark (1984). Other important records for eastern Africa include those by Selenka (1867) and Ludwig (1899) from Zanzibar as Holothuria botellus; by Haacke (1880) and Ludwig (1883) from Mauritius; by Ludwig (1883) from Madagascar; by Lampert (1885) and Ludwig (1899) from the Seychelles. A.M. Clark \& Rowe (1971) show an Indo-Pacific (with the Red Sea, see also Tortonese, 1955) distribution.

\section{Genus Labidodemas Selenka, 1867}

Labidodemas pertinax Ludwig, 1875. P1. 2D

Material examined. KKiun/9919 (one specimen); KKiun/9920 (two specimens).

Taxonomic description. See Cherbonnier, 1988: 51-53; figure 17, p. 52; Rowe \& Gates, 1995: p. 304.

Field description. Uniform white dorsally with a pinkish shine ventrally. Mouth terminal, surrounded by a $5 \mathrm{~mm}$ wide dark purple to brown ring. Trivium with distinct radial areas containing long cylindrical yellow to brown tube feet (median ambulacrum in two rows); bivium with fewer short white conical tube feet spread over the ambulacral and interambulacral areas. Mouth terminal, surrounded by 15 to 20 small feeding tentacles. Anus terminal, sometimes surrounded by conical papillae. Skin thin but leathery.

Abundance in the Kiunga Marine Reserve. Common, although this species is rarely seen, due to its hiding behaviour. Not reported by Obura et al. (1998) from the Kiunga Marine Reserve.

Local Distribution. Two species of Labidodemas are known to occur in the Indian Ocean: Labidodemas rugosum and Labidodemas pertinax (Rowe, 1969). In eastern Africa Labidodemas pertinax is only known from a few localities: Iles Glorieuses (North of Madagascar) (Cherbonnier, 1988). However its range stretches further North towards the Arabian Gulf (Price, 1981) and the Red Sea (Price, 1982) and West via the Bay of Bengal, the East Indies, North Australia and the Philippines up to Hawaii (see Clark \& Rowe, 1971 for distribution table).

Remarks. All the specimens were seen under coral boulders on sand gravel or on coarser coral rubble.

\section{Family Stichopodidae Haeckel, 1886}

Genus Stichopus Brandt, 1835

Stichopus chloronotus Brandt, 1835. P1. 2D

Material examined. The specimen from the Kiunga Marine Reserve could not be preserved adequately and was discarded. The picture $\mathrm{D}$ on pl. 2 leaves no doubt over the identification. Taxonomic description. See Cherbonnier, 1988: 146-147; figure 60, p. 149.

Field description. Medium sized species up to $150 \mathrm{~mm}$ long and up to $60 \mathrm{~mm}$ wide. The body colour of live specimens varies from dark green to black-brown. Trivium distinctively 
flattened, slightly lighter colour than bivium. The mouth is positioned ventrally and is surrounded by large dark green papillae and 16 to 20 white or grey (after preservation) peltate tentacles. Anus terminal. Relatively long dark green cylindrical tube feet cover the whole ventral side, posteriorly in four distinct rows. On the dorsal side two rows of large conical papillae of the same body colour but with yellow-orange distal ends. The bivium is separated from the trivium by a single row of these papillae. Skin smooth, 3 to $4 \mathrm{~mm}$ thick.

Abundance in the Kiunga Marine Reserve. Very rare, only recorded as a single specimen from a single locality (Hindi). Not reported by Obura et al. (1998) in the Kiunga Marine Reserve. Local distribution. Not reported from Kenya by Humphreys (1981), nor by Tortonese $(1949 ; 1951 ; 1980)$ from Somalia. It is here described for the first time from Kenya, although it is a well-known tropical Indo-Pacific (see Clark \& Rowe, 1971: 178-179; Rowe \& Doty, 1977) and Red Sea (Price, 1982) species ranging from East Africa to Hawaii. The most representative local records are those by Selenka (1867) who reports it from Zanzibar; by Haacke (1880) as Stichopus cylindricus and Ludwig (1883) as Stichopus (Perideris) chloronotus from Mauritius; by Sloan et al. (1979) from Aldabra; and by Clark (1984) from the Seychelles.

\section{Stichopus herrmanni Semper, 1868. Pl. 2 E}

Material examined. None from Kiunga, however picture E. on pl. 2 leaves no doubt over the identification.

Taxonomic description. See Rowe \& Gates, 1995: 324; Massin, 1996a: 35-38; figure 24, p. 37; Massin, 1999: 63-65; figure 52, p. 64.

Field description. Large species, up to $250 \mathrm{~mm}$ long and to $65 \mathrm{~mm}$ wide. Body form is squarish, with a smooth surface. The colour of live animals is uniform bright olive-green dorsally and ventrally. Dorsal surface with large transverse scars. Mouth ventral with 16 to 18 greenish tentacles. Anus terminal, without anal teeth or papillae. On the flattened ventral side cylindrical podia positioned both on the ambulacra and the interambulacra. Conical, light green papillae with dark green stripes and yellow to orange distal tips, lateral and dorsal, for the latter side only in the ambulacral areas. Body wall from 3 to $5 \mathrm{~mm}$ thick, smooth.

Abundance in the Kiunga Marine Reserve. Rare. First record for the Kiunga Marine Reserve. Local distribution - Recorded from Mombasa by Levin (1979) as Stichopus variegatus. It is a well-known Indo-Pacific species (Rowe \& Gates, 1995). However, as Massin (1999) notes, its exact distribution is problematic due to confusion with Stichopus monotuberculatus.

Stichopus cf. monotuberculatus (Quoy \& Gaimard, 1833). Pl. 2F, G, H

Material examined. KKiun/9950 (two specimens).

Taxonomic description. See Cherbonnier, 1952: 23-25, pl. 3 figure 4, text-figure 8 a-t; Massin, 1996b: 163-164; figure 9, p. 165; figure 10, p. 166; pl. 1C, D.

Field description. Large species, in life up to $350 \mathrm{~mm}$ long and $80 \mathrm{~mm}$ wide. Colour in life: dorsal side from grey green to orange-brown with dark green to black patches, ventral side grey-green with numerous small dark patches. In alcohol the colours fade to light green with patches of light brown. Ventral side flattened, dorsal side swollen, giving the animal a squarish view in cross-section. Mouth ventral surrounded by 20 large tentacles surrounded in turn by a circle of large papillae. Anus terminal, without anal teeth or papillae. Large cylindrical, yellowish brown tube feet in trivium in ambulacral areas only. Large conical papillae distributed more or less randomly in bivium, but with a distinct fringe of 8-10 larger papillae laterally. Skin rather rough compared to the other Stichopus species found in the region. 
Abundance in the Kiunga Marine Reserve. Common. observed at several localities in the Kiunga marine reserve, although not reported by Obura et al. (1998).

Local distribution. Stichopus monotuberculatus is reported here as a first record for Kenya. It was seen by one of us (YS) further south, Pemba Island, Tanzania. Neither Humphreys (1981), nor Tortonese $(1949,1951,1980)$ found it in the immediate surroundings. It is however an expected species since, Massin's distribution map (1996b, map 3, p. 174) shows an Indo-Pacific distribution from the Red sea and Madagascar to Eastern Islands, and from Japan to Australia.

Remarks. The specimens discussed here were only seen at night, although one of us (YS) observed a specimen at Pemba Island (Tanzania) foraging during the day. It is with some hesitation that we refer this species to $S$. monotuberculatus. Although the spicules match the descriptions given by Cherbonnier (1952) and Massin (1996b), the colouration and the pattern of the body wall is somewhat different: the "numerous white spots, often clumped together forming a whitish surface, and deep brown spots" (after Massin, 1996b) are largely absent from our specimens. Pl. 2F and G depict the largest specimen found in the Kiunga Marine Reserve. Pl. 2H shows the spicules found in the various body parts. More specimens of different sizes from different localities are needed to clarify the identity of our specimens.

Order Dendrochirotida Grube, 1840

Family Sclerodactylidae Panning, 1949

Subfamily Cladolabinae Heding \& Panning, 1954

Genus Afrocucumis Deichmann, 1944

Afrocucumis africana (Semper, 1868)

Material examined. KKiun/9918 (four specimens).

Taxonomic description. See Cherbonnier, 1988: p. 218-220; figure 95, p. 219.

Field description. Small species, length up to $60 \mathrm{~mm}$, width up to $10 \mathrm{~mm}$, tapering at both ends. Total body surface homogeneous dark green to brown. Mouth and anus terminal. Mouth surrounded by 19 small dendritic tentacles. Tube feet long, cylindrical, of the same colour as the rest of the body, distributed ventrally and dorsally in the ambulacra.

Abundance in the Kiunga Marine Reserve. Rare, maybe common. Only observed in one locality in the reserve. Not reported from the Kiunga Marine Reserve by Obura et al. (1998). Local distribution. It was previously recorded from southern Somalia (Gesira and Bender Mtoni) by Tortonese (1980) and from Mida Creek, Watamu Marine Park, and Kibirijini in Kenya by Humphreys (1981). Other important local records include those by Sloan et al. (1979) from Aldabra; by Clark (1984) from the Seychelles; by Ludwig (1887) as Pseudocucumis theeli from Zanzibar; and Heding and Panning (1954) as Orcula cucumiformis from Zanzibar. Massin (1999, figure 79: p. 96) shows an Indo-Pacific distribution from East Africa (excluding the Red Sea) to the Fiji Islands.

Remarks. Due to its small size and its burrowing behaviour this species is probably easily overlooked.

\section{ACKNOWLEDGEMENTS}

We wish to thank J. Church, WWF-project manager at the Kiunga Marine Reserve. She and her excellent team provided us with logistics and in-depth knowledge of the collection and observation sites within the Reserve. We also wish to thank D. Obura for his aid in preparing 
this expedition. M. Jangoux provided access to his extensive collection of reprints on echinoderms. Financial support came from the Research Council (OZR) of the Free University Brussels (VUB), and from the Flemish Fund for Scientific Research (FWO). Authorisation to study the Kenyan echinoderms came from the Office of the President through J.E. Ekirapa. The field assistance of Bruno Van Bogaert who helped with the collection of the specimens is greatly appreciated. This work would not have been possible without Dr C. Massin who kindly provided the necessary literature, checked the holothurian identifications and reviewed the earliest drafts.

\section{REFERENCES}

Agassiz, A. (1872). Revision of the Echini. Illustrated Catalogue of the Museum of Comparative Zoology, Harvard University 7(1): vii-xii + 242, pls A-G.

Bell, F.J. (1884). Echinodermata. In: Coppinger R.W (ed.). Report on the Zoological collections made in the Indo-Pacific Ocean during the voyage of H.M.S. "Alert", 18811882. London: $117-177$ \& 509-512, pl. 8-17 \& 45.

Bell, F.J. (1903). Report on a collection of echinoderms from the neighbourhood of Zanzibar. Annals and Magazine of Natural History, London (7) 12: 244-248.

Cherbonnier, G. (1952). Les holothuries de Quoy \& Gaimard. Mémoire de l'Institut royal des Sciences naturelles de Belgique, Deuxième série 44: 1-50+3 pls.

Cherbonnier, G. (1980). Holothuries de Nouvelle-Calédonie. Bulletin du Muséum national d'Histoire naturelle de Paris, Quatrième série, 2, section A (3): 659-700.

Cherbonnier, G. \& J.P. Féral (1984). Les Holothuries de Nouvelle-Calédonie. Deuxième contribution (Première partie: Synallactidae et Holothuridae). Bulletin du Muséum national d'Histoire naturelle de Paris, Quatrième série, 6, section A (3): 659-700.

Cherbonnier, G. (1988). Echinodermes: Holothurides. Faune de Madagascar 70: 1-292.

Clark, A.M. \& J. Courtman-Stock (1976). The echinoderms of southern Africa. Trustees of the British Museum (Natural History), London. 277 p.

Clark, A.M. \& F.W.E. Rowe (1971). Monograph of Shallow-water Indo-West Pacific Echinoderms. London, Trustees of the British Museum (Natural History), London. 238 pp.

Clark, A.M. (1984). Echinodermata of the Seychelles. In: D.R. Stoddart, (ed.). Biogeography and Ecology of the Seychelles Islands. Monographiae biologicae 55: 83102. Dr Junk, W. Publishers, The Hague.

Clark, H.L. (1925). A catalogue of the recent sea-urchins (Echinoidea) in the collection of the British Museum (Natural History). London. xxviii +250 pp., 12 pls.

Décary, R. (1924). Liste d'Echinodermes recueillis à Madagascar. Bulletin de l'Académie Malgache 6: 37-41.

Féral, J.P. \& G. Cherbonnier (1986). Les holothurides. In: A. Richard, P. Laboute \& J.L. Menou, (eds). Guides des étoiles de mer, oursins et autres échinodermes du lagon de Nouvelle-Calédonie. ORSTOM, Paris: 1-238.

Haacke, W. (1880). Holothuren. In: K. Möbius (ed.). Beiträge zur Meeresfauna der Insel Mauritius und der Seychellen. Berlin: 46-48.

Heding, S.G. \& A. Panning, (1954). Phyllophoridae. Spolia Zoologica Musei Hauniensis 13: 1-209, 102 figures 
Hoffman, C.K. (1874). Crustacés et Echinodermes de Madagascar et de l'Ile de la Réunion. In: F.P.L. Pollen \& D.C. Van Dam (eds). Recherches sur la faune de Madagascar et de ses dépendances. Leyden 5(2): 1-58, pls i-x [Echinoderms on pp. 45-56, pl. 10]

Hughes, R.N. \& J.C. Gamble, (1977). A quantitative survey of the biota of intertidal soft substrata on Aldabra Atoll, Indian Ocean. Philosophical Transactions of the Royal Society of London Series B - Biological Sciences 279: 327-355.

Humphreys, W.F. (1981). The Echinoderms of Kenya's Marine Parks and Adjacent Regions. Zoologische Documentatie Koninklijk Museum voor Midden Africa, Tervuren, België 19: 1-39.

Kerr, A., D.R. Norris, P.J. Schupp, K.D. Meyer, T.J. Pitlik, D.R. Hopper, J.D. Chamberlain \& L.S. Meyer (1992). Range extension of Echinoderms (Asteroidea, Echinoidea and Holothuroidea) to Guam, Mariana Islands. Micronesica 25 (2): 201-216.

Lambert, J. (1921-22). Echinides vivants et fossiles receuillis à Madagascar par M. Raymond Décary. Mémoires de la Sociéte Académique de l'Aube 85: 3-45, 1 pl.

Lampert, K. (1885). Die Seewalzen (Holothurioidea). In: C. Semper, (ed.). Reisen im Archipel der Philippinen. Wiesbaden (2)4(3): 1-312, $1 \mathrm{pl}$.

Lampert, K. (1896). Die von Dr. Stuhlmann in den Jahren 1888-1889 an der Östkküste Afrika gesammelten Holothurien. Mittheilungen aus dem Naturhistorischen Museum 13: 49-71, 3 figures.

Levin, V.S. (1979). Aspidochirote holothurians of the upper sublittoral zone of Indo-West Pacific: species composition and distribution. Biologia Moria 5: 17-23.

Ludwig, H.L. (1875). Beitrage zur Kenntniss der Holothurien. Arbeiten aus dem zoolog. zootom. Institut in Würzburg 2(2): 77-120, pl. 6-7.

Ludwig, H.L. (1883). Verszeichniss der Holothurien des Kiehler Museums. Bericht der Oberhessischen Gesellschaft für Natur- und Heilkunde 4 (10): 127-137.

Ludwig, H.L. (1887). Drei Mittheilungen über alte und neue Holothurienarten. Abhandlungen der preussischen Akademie der Wissenschaften 54: 1-28, pl. 15.

Ludwig, H.L. (1899). Echinodermen des Sansibargebietes. In: A. Voeltzbow (ed.). Wissenschaftliche Ergebnisse der Reisen in Madagascar und Ost-Africa in den Jahren 1889-95. Abhandlungen der Senckenbergischen naturforschenden Gesellschaft 21: $537-$ 563.

Massin, C. (1996a). Results of the Rumphius Biohistorical Expedition to Ambon (1990). Part 4. The Holothuroidea (Echinodermata) collected at Ambon during the Rumphius Biohistorical Expedition. Zoologische Verhandelingen 307: 1-53.

Massin, C. (1996b). The holothurians of Easter Island. Bulletin de l'Institut royal des Sciences naturelles de Belgique, Biologie 66: 151-178.

Massin, C. (1999). Reef-dwelling Holothuroidea (Echinodermata) of the Spermonde Archipelago (South-West Sulawesi, Indonesia). Zoologische Verhandelingen 329: 1-144.

Massin, C., R. Rasolofonirina, C. Conand, Y. Samyn (1999). A new species of Bohadschia (Echinodermata: Holothuroidea) from the Western Indian Ocean with a redescription of Bohadschia subrubra (Quoy \& Gaimard, 1833). Bulletin de l'Institut royal des Sciences naturelles de Belgique, Biologie 69: 151-160, 1 pl.

Mitsukuri, K. (1912). Studies on Actinopodous Holothuroidea. Journal of the College of Science, Imperial University of Tokyo 39(2): 1-284, 55 figures, 8 pls.

Möbius, K. (1880). Beiträge zur Meeresfauna der Inseln Mauritius und der Seychellen. Berlin: 1-352, 22 pls. [Echinoderms on pp. 46-50].

Mortensen, T. (1928). A monograph of the Echinoidea 1. Cidaroidea. Copenhagen. 551 pp., 173 figures, 88 pls. 
Mortensen, T. (1931). Echinodermata. Faune des Colonies françaises 4: 590-596.

Mortensen, T. (1935). A monograph of the Echinoidea 2. Bothriocidaroida, Meonechinoida, Lepidocentroida and Stiridonta. Copenhagen. 647 pp. 377 figures, 89 pls.

Mortensen, T. (1940). A monograph of the Echinoidea 3(1). Aulodonta. Copenhagen. 370 pp., 196 figures, 77 pls.

Mortensen, T. (1943a). A monograph of the Echinoidea 3(2). Camarodonta 1. Copenhagen. 553 pp., 321 figures, 56 pls.

Mortensen, T. (1943b). A monograph of the Echinoidea 3(3). Camarodonta 2. Copenhagen 446 pp., 215 figures, 66 pls.

Mortensen, T. (1948). A monograph of the Echinoidea 4(2). Clypeasteroida. Copenhagen. 471 pp., 258 figures, 72 pls.

Obura, D., J. Church, H. Mwadzaya, E. Wekesa, N. Muthiga (1998). Rapid assessment of coral reef biophysical and socioeconomic conditions in the Kiunga Marine National Reserve, Kenya: methods development and evaluation. Technical report prepared for FAO and UNEP-Water Branch, Nairobi, Kenya.

Panning, A. (1941). Über einige Ostafrikanische Seewalzen und ihre Eignung zur Trepanggewinnung. Thalassia $6(8)$ : 1-18.

Panning, A. (1944). Die Trepangfischerei. Mitteilungen aus dem Hamburgischen Zoologichen Museum und Institut 49: 2-76, 40 figures.

Pearson, J. (1913). Notes on the Holothuroidea of the Indian Ocean. Spolia Zeylanica 9(34): 49-101, pls 5-14.

Peters, W. (1854). Über die an der Küste von Mossambique beobachteten Seeigel und insbesondere über die Gruppe der Diademen. Abhandlungen der preussischen Akademie der Wissenschaften 1854: 101-119, 1 pl.

Peters, W. (1855). Seeigel von Mossambique. Abhandlungen der preussischen Akademie der Wissenschaften 1855.

Pfeffer, G. (1896). Ostafrikanische Echiniden, Asteriden und Ophiuriden, gesammelt von Herrn Dr. F. Stuhlmann im Jahre 1888 und 1889. Mitteilungen aus dem Hamburgischen Zoologichen Museum und Institut 13: 43-48.

Price, A.R.G. (1981). Studies on the echinoderm fauna of the western Arabian Gulf. Journal of Natural History 15: 1-15.

Price, A.R.G. (1982). Echinoderms of Saudi Arabia. Comparisons between echinoderm faunas of Arabian Gulf, SE Arabia, Red Sea and Gulfs of Aqaba and Suez. Fauna of Saudi Arabia 4: 3-21.

Quoy, J.R.C. \& J.P. Gaimard (1833). Zoologie: Zoophytes. In: Voyage de la corvette de l' "Astrolabe", exécuté par l'ordre du roi pendant les années 1826-1829 sous le commandement de M.J. Dumont d'Urville: 1-390, pls 1-26. Paris.

Richmond, M.D. (ed) (1997). A Guide to the Seashores of Eastern Africa. 448 pp. Sea Trust, Zanzibar.

Rowe, F.W.E. (1969). A review of the family Holothuriidae (Holothuroidea: Aspidochirotida). Bulletin of the British Museum of natural History (Zoology) 18(4): 119170.

Rowe, F.W.E. \& J.E. Doty (1977). The shallow-water holothurians of Guam. Micronesia 13(2): 217-250, 9 figures

Rowe, F.W.E. \& J. Gates (1995). Echinodermata. In: A. Wells, (ed.). Zoological Catalogue of Australia: vol. 33, i-xiii, 1-510. CSIRO Australia, Melbourne. 
Rowe, F.W.E. \& M.D. Richmond (1997). Echinodermata. In: M.D. Richmond, (ed.). $A$ guide to the seashores of eastern Africa and the western Indian Ocean Islands: 290-321. The SEA Trust, Zanzibar. $448 \mathrm{pp}$.

Russo, A. (1932). Echinodermi raccolti dal Prof. L. Stanzo nella campagna della R.N. Ammiraglio Magnaghi in Mar Rosso e zone viciniori 1923-1924. 3. Echinoidea, Ophiuroidea. Memorie Reale Comitato talassographico italiano, Venezia 194: 1-5, 4 figures.

Ruwa R.K. (1989). Macrofaunal composition and zonation on sandy beaches at Gazi, Kanamai and Malindi Bay, Kenya. Kenya Journal of Sciences, Series B, 10 (1-2): 31-45.

Selenka, E. (1867). Beiträge zur Anatomie und Systematik der Holothurien. Zeitschrift für wissenschaftliche Zoologie 17: 291-374, pls 17-20.

Semper, C. (1869). Die Holothurien Ostafrika's. In C.C. von der Decken, Reisen in Ost Afrika. Leipzig \& Heidelberg 3(1): 117-122, 1 pl.

Sloan, N.A., A.M. Clark, J.D. Taylor (1979). The echinoderms of Aldabra and their habitats. Bulletin of the British Museum of natural History (Zoology) 37(2): 81-128.

Théel, H. (1886). Holothuroidea. Part 2. Report of the scientific Results of the Voyage of the Challenger (Zoology) 39: 1-290, pl. 1-16.

Tortonese, E. (1936). Echinodermi del Mar Rosso. Annali del Museo civico di Storia Naturale Giacomo Doria, Genova 59: 202-245; 8 figures.

Tortonese, E. (1949). Echinodermi della Somalia Italiana. Annali del Museo civico di Storia Naturale Giacomo Doria, Genova 64: 30-42.

Tortonese, E. (1951). Contributo allo studio dell'Echinofauna della Somalia. Atti della Società Italiana di Scienze Naturali 90: 237-250.

Tortonese, E. (1955). Spedizione subacquea Italiana nel Mar Rosso. Ricerche Zoologiche. II Echinodermi. Rivista di Biologia Coloniale 13: 25-48, 1 pl.

Tortonese, E. (1980). Researches on the coast of Somalia. Littoral Echinodermata. Italian Journal of Zoology 5: 99-139. 